$11^{\text {th }}$ International Conference

on Civil and Architecture

Engineering

ICCAE-11-2016

\title{
PERFORMANCE OF REINFORCED CONCRETE BEAM COLUMN CONNECTIONS EXPOSED TO FIRE UNDER CYCLIC LOADING
}

\author{
Prof. Khalid M. Heiza ${ }^{1}$, Eng . Mahmoud Saied Taha ${ }^{2}$, Prof. Monier H. Soliman ${ }^{3}$ \\ ${ }^{1}$ Professor of RC Structures Civil Engineering Department, \\ Vice Dean, Faculty of Engineering, Menofia University, Egypt. \\ ${ }^{2}$ Ph.D. candidate, Faculty of Engineering,Thesis Menofia University, Egypt. \\ ${ }^{3}$ Late professor of RC Structures, Faculty of Engineering, Menofia University, Egypt.
}

\begin{abstract}
Fire could dramatically reduces the characteristic strength of the reinforced concrete elements [1,2]. A lot of efforts has been devoted to study the effect of fire on the reinforced concrete elements during past decades. These previous studies focused on evaluating fire resistance for concrete elements, [3] and provide some recommendations of structural fire-resistance [4] such as cover thickness, reinforcement ratio and coating materials. A lot of research focused on RC columns [5,6,7], beams [8] and slabs [9] which has been exposed to fire, where less efforts aimed to study the effect of fire on $\mathrm{RC}$ beam column connections $[10,11,12]$. The main objective of the present work is to study the structural behavior of reinforced concrete beam-column connections exposed to fire under cyclic loading $[13,14]$ and to evaluate the reduction in concrete strength during fire process. To achieve these goals, this research consists of two parts, the first part is experimental program, and the second is the theoretical analysis. The experimental program include 12 one- third scale specimens half of them casted from normal concrete and other half from SCC. The effect of some parameters on the connection's behavior like reinforcement ratio, type of concrete (normal or selfcompacted concrete) [15] and exposure fire time were studied. Experimental program extended also to study heat distribution inside RC beam-column connections by measuring temperature at 65 point Distributors at 5 sections all over the RC connection. Theoretical analysis was done by using finite element program (ANSYS12.1) and a comparison between experimental program and theoretical analysis was done SCC showed good properties in hardening state when exposed to high temperature compared with normal concrete [16]. Increasing reinforcement ratio of RC connections increases its fire resistance Good agreement between analytical and experimental work was observed.
\end{abstract}

Key words: self-compacted Concrete, Fire, Reinforcement ratio, Fire duration, Cracks, Failure.

\section{INTRODUCTION}

The behavior of reinforced concrete structures and its modes of failure have been extensively studied. Particularly, degradation of concrete strength due to short-term exposure to elevated temperature (fire) has attracted attention in last decades[17]. The behavior of concrete exposed to fire depends on its mix composition and has been 
determined by complex interactions during heating process. The modes of concrete failure under fire exposure are been varied according to the nature of the fire, the loading system [18], and the type of structure. Moreover, failure could happen due to different reasons such as reduction of bending or tensile strength, loss of shear or torsion strength, loss of compressive strength, and more [19].

Building design manual and building codes require some provisions of structural fireresistance to ensure building integrity for a certain period under fire conditions[20]. Such provisions allow safely evacuation of occupants and access for firefighters. However, the behavior of the building after fire and whether it is worthy to repair it or not, is another point of interest that needs more investigation. Consequently, this research is aimed to investigate the effect of fire on the behavior of reinforced beamcolumn connections. To achieve this objective, a laboratory experiments in conjunction with theoretical analysis by using a finite element program have been performed to simulate the behavior of beam- column connections exposed to fire. The results of these experimental and theoretical analysis were presented and discussed

\section{2-EXPERIMENTAL WORK}

\subsection{Specimens $\square$ details and reinforcement.}

In the experimental work there are twelve one -third (1/3) scale specimens as shown in figure (1) which were designed and constructed according to (ECCP 2007) [21] Owing to concrete type, reinforcement ratio and exposure time to fire, the specimens were divided into four groups as following:-

Group (A) of normal concrete and consists of three specimens (A1) as a control specimen not exposed to fire and (A2, A3) exposed to fire for 1 and 2 hour respectively. Reinforcement of this group as shown in figure (2).

Group (B) from normal concrete and consists of three specimens (B1) as a control specimen and ( B2, B3) exposed to fire for 1 and 2 hour respectively. Reinforcement of this group as shown in figure (3).

Group (C) from self-compacted concrete and consists of three specimens (C1) as a control specimen and (C2, C3) exposed to fire for 1 and 2 hour respectively. Reinforcement of this group as shown in figure (2).

Group (D) from SCC and consists of three specimens (D1) as a control specimen not and ( D2, D3) exposed to fire for 1 and 2 hour respectively. Reinforcement of this group as shown in figure (3).

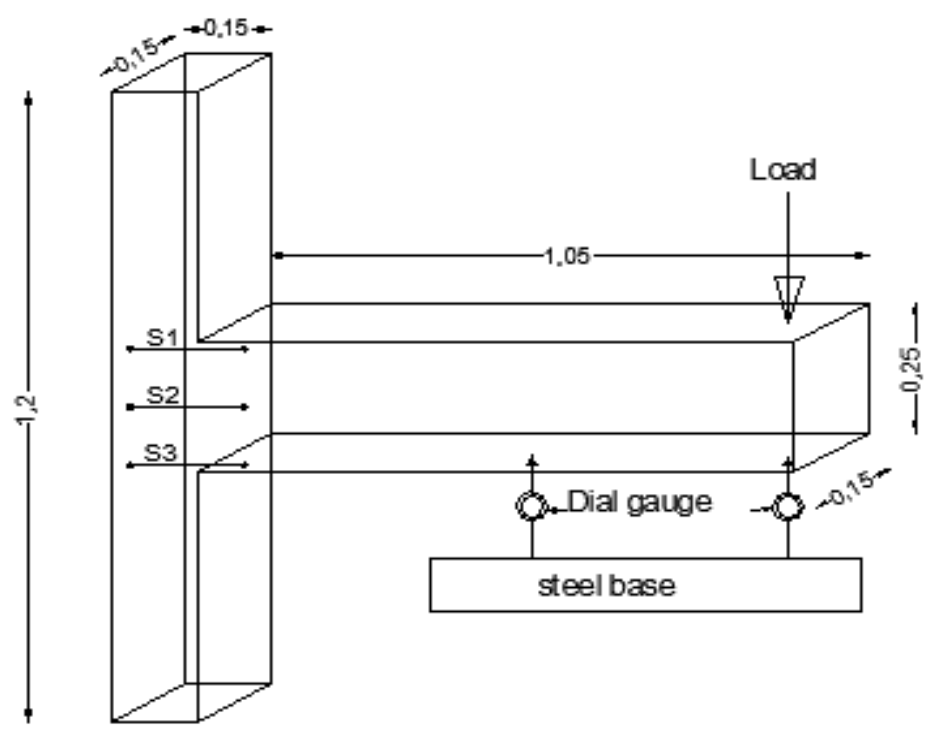


Figure (1) Specimen Geometry and Load Argument of RC Beam-Column Connection

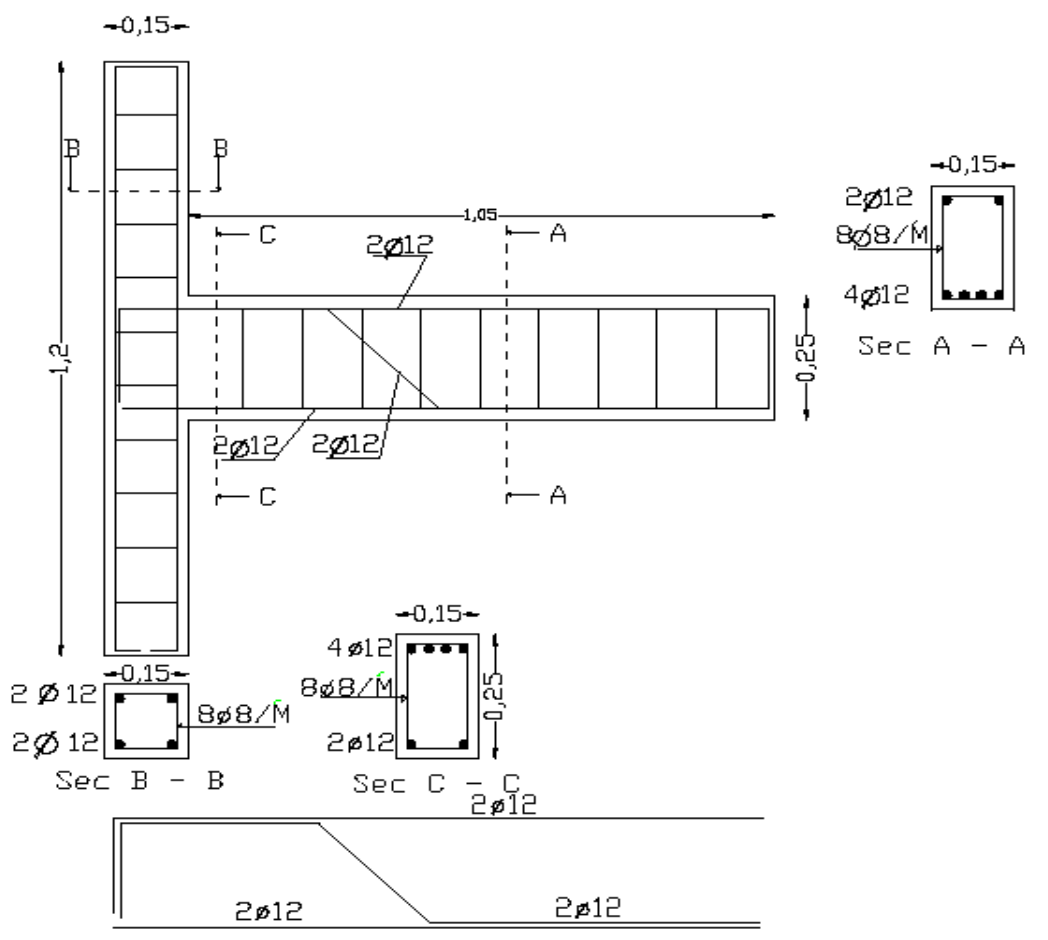

Figure(2) Dimensions and Reinforcement details of group (A) and (C) of RC Beam-Column Connections

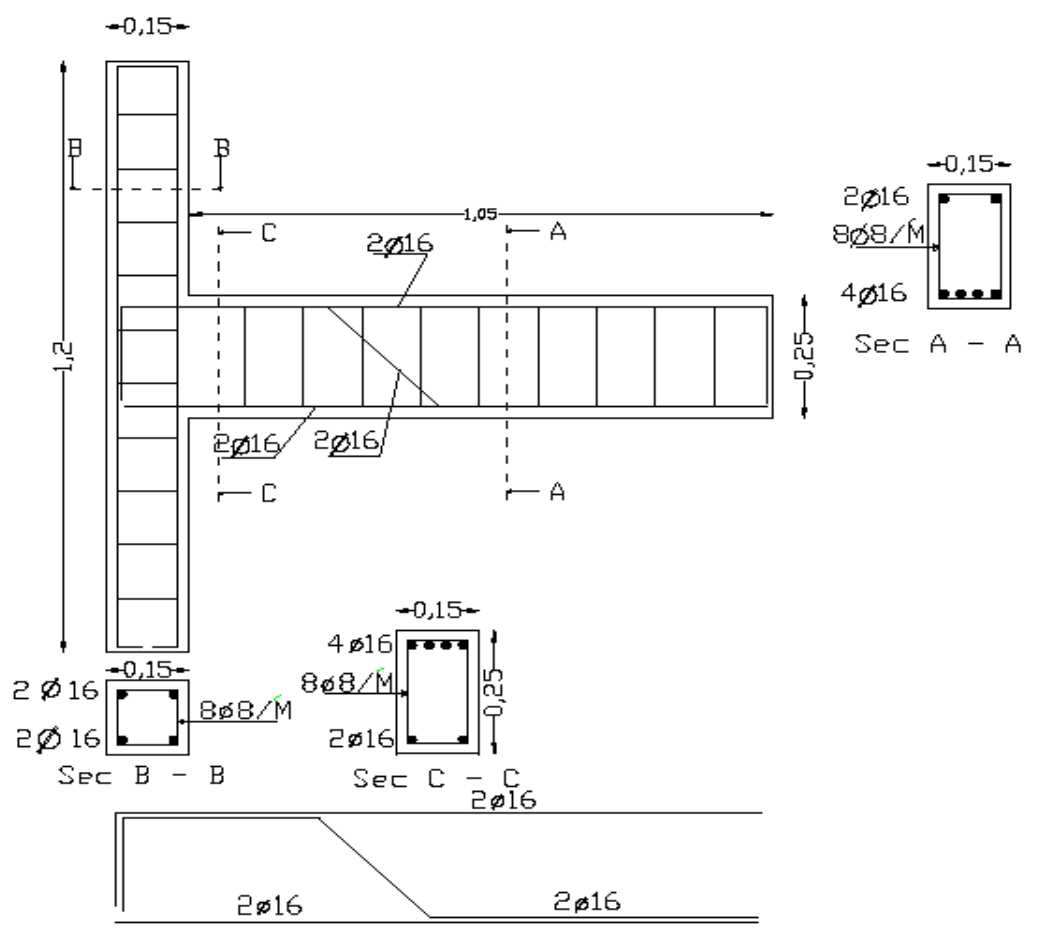

Figure(3) Dimensions and Reinforcement details of group (B) and (D) of RC Beam-Column Connections

2.2 Fixation of thermocouples at connection zone. 
Relation between heat distribution inside $\mathrm{RC}$ beam column connection during fire and behavior of RC beam column connection was an important part in this thesis. For this reason, 5 sections were taken to record temperature distribution inside connection as shown in Figure (4) and 13 thermocouple nodes were distributed in each section. Thermocouples were numbered at their free ends which lie outside furnace during fire to can measure temperature in each position without mistake.

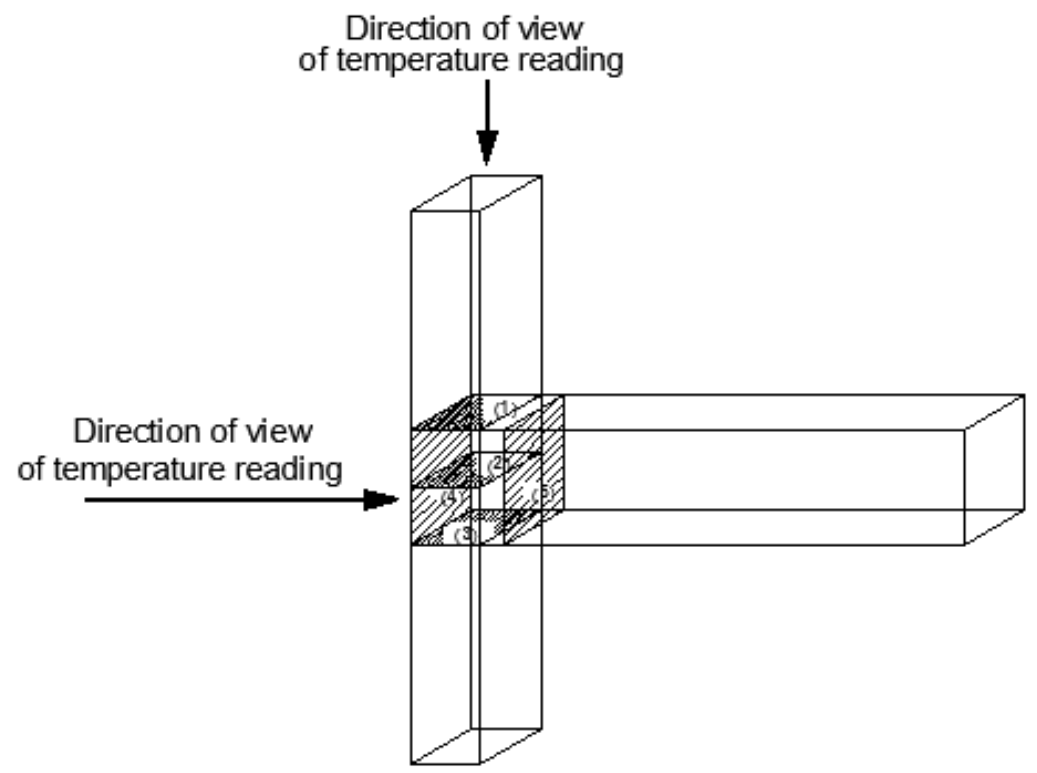

Figure (4) Arrangement of five Sections for Measuring the Temperature distribution inside the RC Specimen

\subsection{Concrete Mix Design}

Four mix design of SCC representing four series and other four mix designs of Normal concrete (NC) were used in this study to produce various concrete strength. Tables (1) and (2) give the different mix proportion to produce one meter cube of SCC and NC respectively and the average compressive strength for each mix. The Second mix design in both table (1) and (2) were chosen to produce self-compacted concrete and normal concrete respectively.

Table (1) The mix proportion to produce $\left(\mathrm{1M}^{3}\right)$ of self- compacted concrete (SCC).

\begin{tabular}{|c|c|c|c|c|}
\hline \multirow{2}{*}{ Material (kg/ M $\left.\mathbf{M}^{\mathbf{3}}\right)$} & \multicolumn{4}{|c|}{ Mix code } \\
\cline { 2 - 5 } & Mix (1) & Mix (2) & Mix (3) & Mix (4) \\
\hline Cement & 400 & 425 & 400 & 400 \\
\hline sand & 1000 & 686 & 1000 & 715.5 \\
\hline Dolomite & 1000 & 838 & 1000 & 874.5 \\
\hline Fly ash & 40 & 85 & 40 & 40 \\
\hline VEA (Viscocrete 5-400) & 10 & 17 & 10 & 10 \\
\hline Water & 120 & 148.75 & 120 & 140 \\
\hline $\begin{array}{c}\text { Average compressive } \\
\text { strength (kg/cm }\end{array} \mathbf{F}_{\text {cu 28 }}$ & 420 & 445 & 460 & 485 \\
\hline
\end{tabular}


Table (2) The mix proportion to produce $\left(1 \mathrm{M}^{3}\right)$ of normal concrete $(\mathrm{NC})$.

\begin{tabular}{|c|c|c|c|c|}
\hline \multirow[t]{2}{*}{ Material $\left(\mathrm{kg} / \mathbf{M}^{3}\right)$} & \multicolumn{4}{|c|}{ Mix code } \\
\hline & Mix (1) & Mix (2) & Mix (3) & Mix (4) \\
\hline Cement & 300 & 350 & 400 & 425 \\
\hline sand & 630 & 620 & 600 & 580 \\
\hline Dolomite & 1180 & 1150 & 1120 & 1100 \\
\hline Water & 160 & 160 & 165 & 170 \\
\hline $\begin{array}{l}\text { Average compressive } \\
\text { strength }\left(\mathrm{kg} / \mathrm{cm}^{2}\right) \mathbf{F}_{\mathrm{cu}} 28\end{array}$ & 294 & 359 & 402 & 429 \\
\hline
\end{tabular}

\subsection{Specimens $\square$ Mixing, Placing and Curing}

Mixing was performed for concrete contents for 5 minutes to get good mixing for concrete then the concrete was charged out from the mixer and fresh testes were done like slump test, modified slump test v-funnel and J- ring System of curing consisted of a base of clean sand with thickness $10 \mathrm{~cm}$ then a lower layer of sackcloth then reinforced concrete models and also complete cover of sackcloth to upper surface and sides of models. This system of curing was submerged with water each day and this continue for 28 days.

\subsection{Test Setup}

Exposure of RC beam-column connections to direct fire in a furnace under loading on the beam were done Used furnace was designed to agree with the standard fire test curves of B.S 476 [22], ASTM-E119 [23], and ISO 834 [24] It was designed to contain only the beam-column connection where exposure to fire will done The furnace was made from steel sheets ( $2 \mathrm{~mm}$ thickness) and consists of two parts which together form the complete furnace as shown in fig (5 and 6). A comparison between furnace temperature and ASTM-E119 is shown in fig.(7) as a calibration curve.

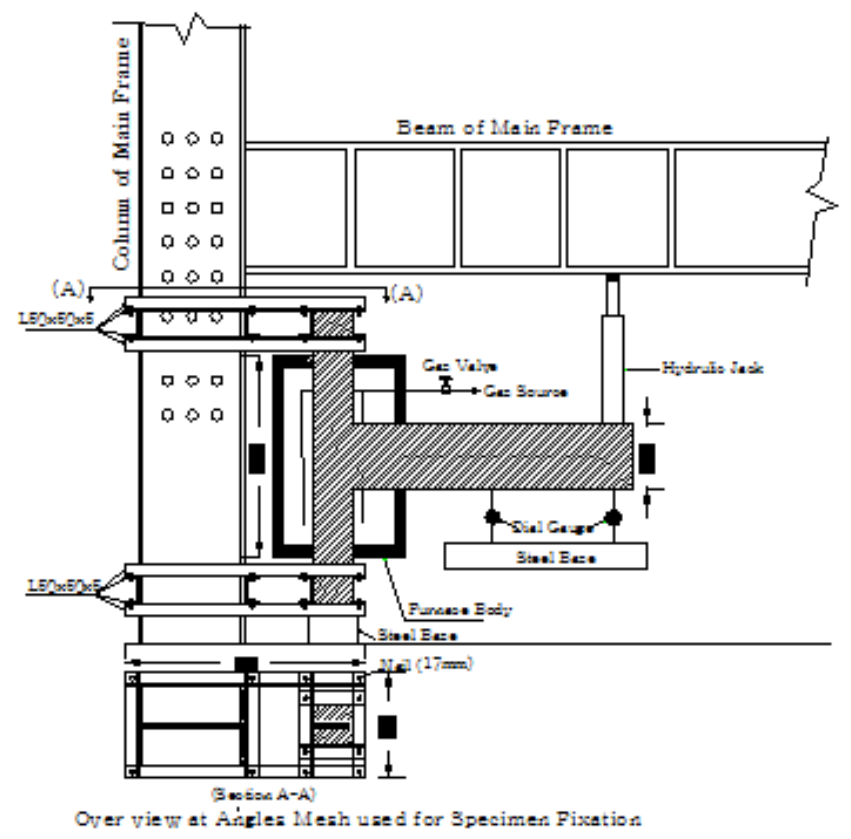

Figure (5) RC Specimen Fixation During Testing 


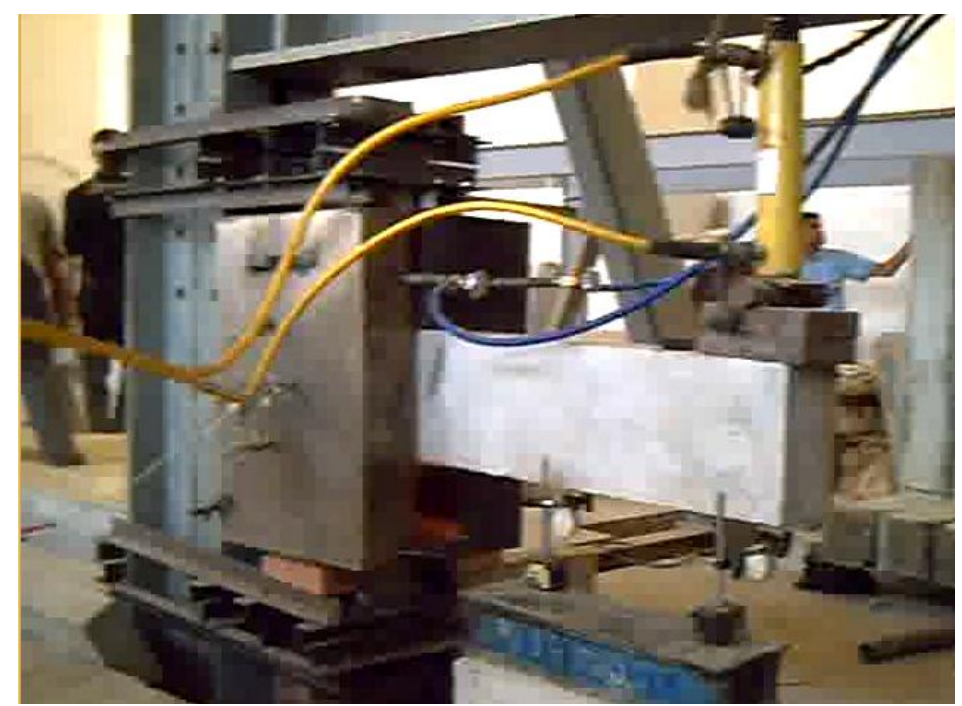

Figure (6) Typical and actual Shape of RC Specimen During Testing

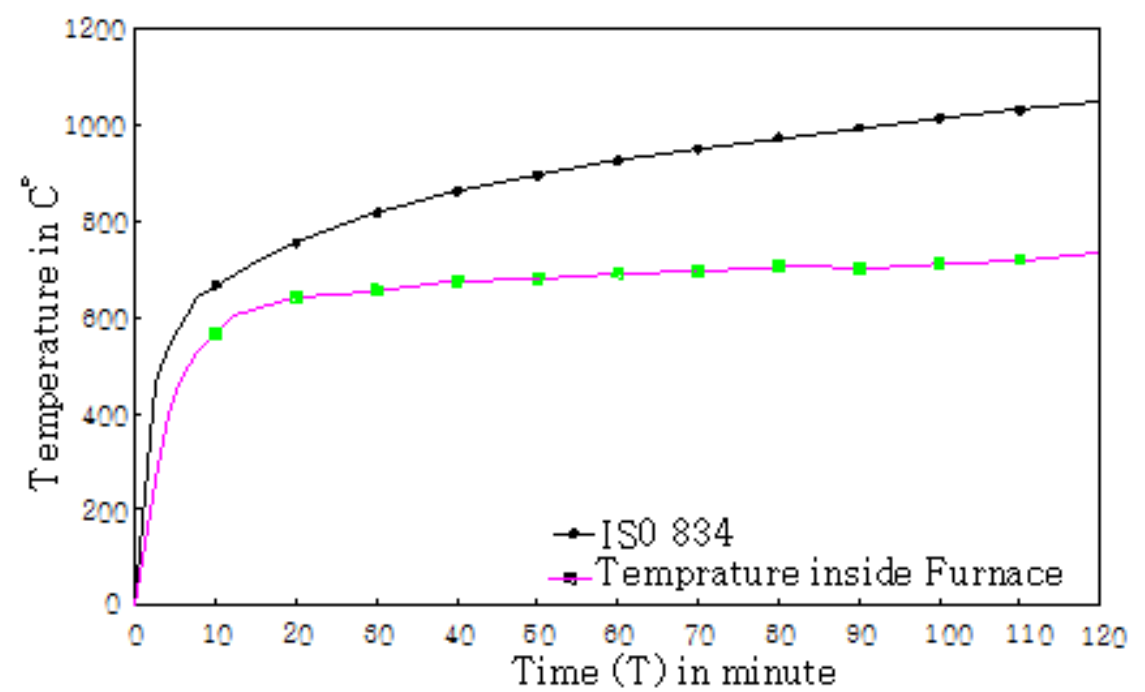

Figure (7) Calibration Curve of Furnace and Time-Temperature Relation Compared to ISO 834

\subsection{Testing Procedures}

The Specimens were cyclic loaded and at each load increasing or decreasing deflection, longitudinal strains and crack propagation were recorded. At the time of testing, the specimen was placed vertically. The two ends of the RC column were fixed to ensure good distribution of the column axial load. The applied load was increased by a hydraulic jack at a key point connected with testing machine where the increasing and decreasing of the applied load was by rate of $100 \mathrm{~kg}$. Two dial gauges (A, B) of total capacity of $50 \mathrm{~mm}$ length and $(0.01) \mathrm{mm}$ accuracy were used for deflection measurement at the bottom of surface of the beam. One of the previous mentioned dial gauges (A) was fixed at the bottom face at the end of the beam below the loading point while Another dial gauge (B) was fixed at the bottom surface of beam at the point lies in mid span of the beam. Strain was measured using digital dial gauge of $0.01 \mathrm{~mm}$ accuracy. Control specimens were firstly tested at room temperature and both initial crack load and failure load were recorded. Deflection at positions (A and B), Strain (S1,S2 and S3) and crack propagation with each load cycle were recorded. For the 
specimens tested under fire, each specimen was exposed to nearly 15 cycle of loading before exposing to fire where maximum applied load is not exceed the initial crack load gotten form testing of control specimen then the specimen was exposed to fire. The furnace was set-up to contain only beam-column connection where connection exposed to temperature $600^{\circ} \mathrm{C}$ within 6 minutes from starting of fire. $\mathrm{RC}$ specimens were fired under loading equal to initial crack load taken from control specimen. Exposure time was 1 or 2 hour as required. At the end of firing process, the front part of furnace was taken aside and cycles of loading were begun combined with recording of deflection, strain and cracks at each load increment until reaching to failure load.

\subsection{Temperature Measuring}

Temperature inside specimen at (65) points distributed on 5 sections as shown in (Figures 4 ) were measured by using thermocouple type (K) which can bears direct fire up to $900{ }^{\circ} \mathrm{C}$. One end of each thermocouple was fixed inside specimen on defined node before casting and other end lies outside furnace during heating where this end will connect to Digital Multimeter to read temperature inside specimen. As a result of heating to specimens, electrical current was born in thermocouple which was measured in millivolts unit by the Multimeter. Conversion of measured electrical current to temperature degree were done by using curves as shown in Figure(8) [25]. Temperature degrees measured at different specimens as shown in tables (3and 4)

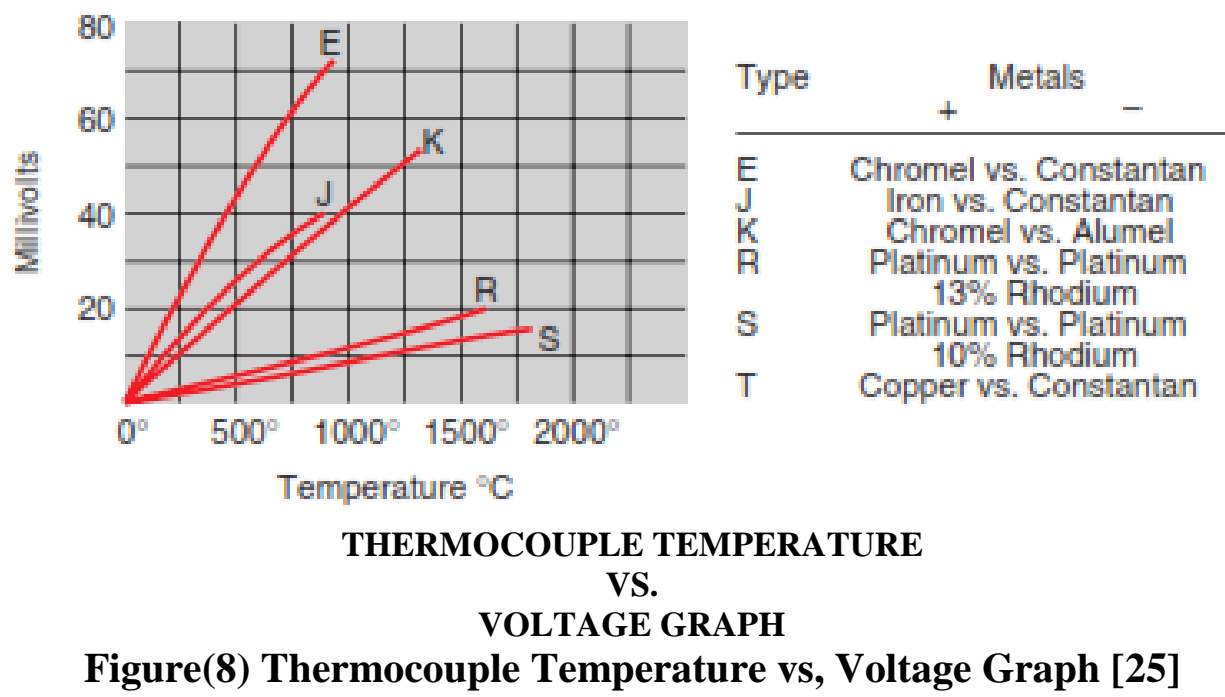




\subsection{Design of RC beam column connection Specimens}

Calculate $\mathrm{M}_{\mathrm{cr}}$ and $\mathrm{P}_{\mathrm{cr}}$

Before Cracking :-

$\mathrm{E}_{\mathrm{cr}}=14000 \sqrt{\mathrm{Fcu} \mathrm{kg} / \mathrm{cm}^{2}}$

$\mathrm{E}_{\mathrm{s}}=2 \times 10^{6} \mathrm{~kg} / \mathrm{cm}^{2}$

$\mathrm{n}$ (modular ratio) $=10$

$\mathrm{A}_{\mathrm{r}}=\mathrm{b} . \mathrm{t}+(\mathrm{n}-1) \mathrm{As}+(\mathrm{n}-1) \mathrm{As}^{\prime}$

$=15 \times 25+(10-1) 8.04+(10-1) \times 4.02=483.54 \mathrm{~cm}^{2}$

$\mathrm{Y}_{\mathrm{t}}=\left[\mathrm{bt}^{2} / 2+(\mathrm{n}-1)\right.$ As x c $\left.+(\mathrm{n}-1) \mathrm{As}^{\prime}\left(\mathrm{t}-\mathrm{c}^{\prime}\right)\right] / \mathrm{Ar}$
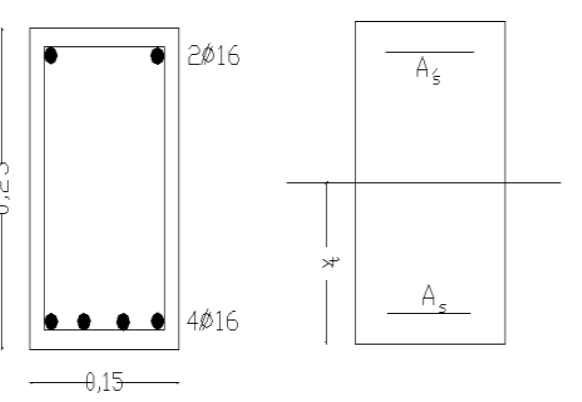

$\mathrm{Y}_{\mathrm{t}}=\left[15 \times 25^{2} / 2+9 \times 8.04 \times 2+9 \times 4.02 \times 23\right] / 483.54$

$\mathrm{Y}_{\mathrm{t}}=11.71 \mathrm{~cm}$

$I_{v}=b t(t / 2-Y t)^{2}+b t^{3} / 12+(n-1) A s(Y t-c)^{3}+(n-1) A s^{\prime}\left(t-Y t-c^{\prime}\right)^{2}$

$\mathrm{I}_{\mathrm{v}}=31199.34 \mathrm{~cm}^{2}$

$\mathrm{F}_{\text {ctr }}=1.9 \sqrt{\mathrm{Fcu}}=1.9 \sqrt{250}=30 \mathrm{~kg} / \mathrm{cm}^{2}$

$\mathrm{M}_{\mathrm{cr}}=\mathrm{F}_{\mathrm{ctr}} \mathrm{Iv} / \mathrm{Yt}=79929.99 \mathrm{~kg} / \mathrm{cm}=0.8 \mathrm{t} . \mathrm{m}$

$\mathrm{P}_{\mathrm{cr}}=\mathrm{Mcr} / \mathrm{L}=0.8 / 1.05=0.762 \mathrm{t}$.

Calculate $\mathrm{P}_{\mathrm{w}}$

After cracking

$\mathrm{n}=15$

$\mathrm{bz} / 2+(\mathrm{n}-1) \mathrm{As}^{\prime}(\mathrm{z}-\mathrm{c})=\mathrm{n}$ As $(\mathrm{d}-\mathrm{z})$

$15 \mathrm{x} \mathrm{z}^{2} / 2+14 \times 4.02(\mathrm{z}-2)=15 \times 8.04 \times(23-\mathrm{z})$

$\mathrm{Z}=11.1 \mathrm{~cm}$

$\mathrm{I}_{\mathrm{w}}=\mathrm{bz}^{3} / 3+\mathrm{nA}(\mathrm{d}-\mathrm{z})^{2}+(\mathrm{n}-1) \mathrm{As}^{\prime}(\mathrm{z}-\mathrm{c})^{2}$

$=428576.87 \mathrm{~cm} 4$

$\mathrm{M}_{\mathrm{wc}}=\mathrm{f}_{\mathrm{c}} \mathrm{I}_{\mathrm{w}} / \mathrm{z}$

$\mathrm{M}_{\mathrm{ws}}=\left[\left(\mathrm{f}_{\mathrm{s}} / \mathrm{n}\right) \mathrm{I}_{\mathrm{w}}\right] / \mathrm{d}-\mathrm{z}$

Take $\mathrm{f}_{\mathrm{c}}=100 \mathrm{~kg} / \mathrm{cm}^{2}$ and $\mathrm{f}_{\mathrm{s}}=2000 \mathrm{~kg} / \mathrm{cm}^{2}$

$\mathrm{M}_{\mathrm{wc}}=2.575 \mathrm{t} . \mathrm{m}$

$\mathrm{M}_{\mathrm{ws}}=3.2 \mathrm{t} . \mathrm{m}$

Take less value of $\mathrm{M}_{\mathrm{wc}}$ and $\mathrm{M}_{\mathrm{ws}}$

$\mathrm{P}_{\mathrm{w}}=\mathrm{M}_{\mathrm{w}} / \mathrm{L}=2.45 \mathrm{t}$

For column $\mathrm{P}_{\mathrm{w}}$ and $\mathrm{P}_{\mathrm{u}}$ calculated as following:-

$\mathrm{P}_{\mathrm{w}}=\mathrm{A}_{\mathrm{c}} \mathrm{F}_{\mathrm{co}}+0.44 \mathrm{~F}_{\mathrm{y}} \mathrm{A}_{\mathrm{sc}}$

$\mathrm{P}_{\mathrm{u}}=0.35 \mathrm{~A}_{\mathrm{c}} \mathrm{F}_{\mathrm{co}}+0.76 \mathrm{~F}_{\mathrm{y}} \mathrm{A}$

Table (3)Temperature Distribution inside RC specimen Exposed to(1hr ) of Fire

\begin{tabular}{|c|c|c|c|c|c|c|c|c|c|c|c|c|c|c|}
\hline \multirow{2}{*}{$\begin{array}{l}\text { Specimen. } \\
\text { code }\end{array}$} & \multirow{2}{*}{$\begin{array}{c}\text { Section } \\
\text { No. }\end{array}$} & \multicolumn{13}{|c|}{ Temperature Reading at Nodes ${ }^{\circ} \mathrm{C}$} \\
\hline & & 1 & 2 & 3 & 4 & 5 & 6 & 7 & 8 & 9 & 10 & 11 & 12 & 13 \\
\hline A2 & 1 & 532 & 302 & 263 & 228 & 270 & 312 & 526 & 532 & 305 & 273 & 222 & 219 & 218 \\
\hline
\end{tabular}




\begin{tabular}{|c|l|l|l|l|l|l|l|l|l|l|l|l|l|l|}
\hline & 2 & 526 & 297 & 259 & 223 & 264 & 303 & 520 & 528 & 299 & 268 & 221 & 215 & 211 \\
& 3 & 519 & 289 & 253 & 217 & 258 & 298 & 513 & 519 & 292 & 261 & 215 & 211 & 209 \\
& 4 & 531 & 529 & 527 & 526 & 524 & 519 & 517 & 541 & 532 & 528 & 529 & 531 & 533 \\
& 5 & 220 & 218 & 217 & 214 & 213 & 210 & 206 & 527 & 299 & 260 & 266 & 304 & 522 \\
\hline B2 & 1 & 538 & 346 & 275 & 235 & 286 & 321 & 534 & 535 & 317 & 285 & 231 & 227 & 223 \\
& 2 & 533 & 306 & 269 & 241 & 284 & 315 & 528 & 531 & 311 & 281 & 226 & 221 & 213 \\
& 3 & 528 & 301 & 264 & 225 & 278 & 311 & 525 & 528 & 308 & 277 & 221 & 215 & 213 \\
& 4 & 534 & 536 & 532 & 527 & 527 & 525 & 518 & 534 & 531 & 530 & 530 & 534 & 536 \\
& 5 & 225 & 222 & 222 & 220 & 219 & 216 & 215 & 534 & 308 & 270 & 273 & 316 & 530 \\
\hline $\mathrm{C} 2$ & 1 & 510 & 289 & 251 & 210 & 248 & 288 & 506 & 509 & 281 & 250 & 208 & 203 & 202 \\
& 2 & 504 & 265 & 228 & 192 & 233 & 272 & 496 & 511 & 267 & 237 & 191 & 189 & 182 \\
& 3 & 496 & 254 & 220 & 188 & 231 & 268 & 491 & 502 & 263 & 230 & 188 & 183 & 180 \\
& 4 & 515 & 514 & 512 & 511 & 509 & 506 & 503 & 515 & 513 & 512 & 512 & 514 & 516 \\
& 5 & 203 & 196 & 193 & 186 & 187 & 183 & 182 & 503 & 266 & 227 & 234 & 234 & 497 \\
\hline $\mathrm{D} 2$ & 1 & 518 & 289 & 251 & 211 & 264 & 298 & 512 & 514 & 294 & 262 & 215 & 204 & 199 \\
& 2 & 514 & 277 & 240 & 211 & 244 & 284 & 506 & 522 & 270 & 249 & 201 & 197 & 193 \\
& 3 & 512 & 273 & 308 & 210 & 242 & 281 & 502 & 518 & 269 & 246 & 200 & 196 & 193 \\
& 4 & 525 & 524 & 523 & 521 & 519 & 517 & 515 & 525 & 523 & 522 & 523 & 524 & 526 \\
& 5 & 204 & 199 & 198 & 193 & 193 & 189 & 190 & 513 & 278 & 239 & 245 & 283 & 507 \\
\hline
\end{tabular}

Table (4)Temperature Distribution inside RC specimen Exposed to (2hr ) of Fire

\begin{tabular}{|c|c|c|c|c|c|c|c|c|c|c|c|c|c|c|}
\hline Specimen. & Section & \multicolumn{10}{|c|}{ Temperature Reading at Nodes ${ }^{\circ} \mathbf{C}$} \\
\cline { 3 - 11 } code & No. & $\mathbf{1}$ & $\mathbf{2}$ & $\mathbf{3}$ & $\mathbf{4}$ & $\mathbf{5}$ & $\mathbf{6}$ & $\mathbf{7}$ & $\mathbf{8}$ & $\mathbf{9}$ & $\mathbf{1 0}$ & $\mathbf{1 1}$ & $\mathbf{1 2}$ & $\mathbf{1 3}$ \\
\hline $\mathbf{A 3}$ & 1 & 649 & 530 & 501 & 458 & 506 & 532 & 656 & 660 & 540 & 501 & 452 & 440 & 431 \\
& 2 & 644 & 527 & 497 & 455 & 502 & 529 & 652 & 657 & 634 & 499 & 449 & 437 & 428 \\
& 3 & 640 & 521 & 493 & 449 & 500 & 524 & 649 & 660 & 531 & 493 & 446 & 430 & 425 \\
& 4 & 661 & 658 & 658 & 657 & 655 & 652 & 649 & 659 & 658 & 657 & 659 & 662 & 663 \\
& 5 & 433 & 450 & 430 & 425 & 425 & 421 & 421 & 643 & 528 & 496 & 503 & 528 & 653 \\
\hline $\mathbf{B 3}$ & 1 & 656 & 542 & 509 & 471 & 511 & 546 & 669 & 667 & 551 & 507 & 462 & 453 & 450 \\
& 2 & 652 & 538 & 506 & 469 & 507 & 544 & 665 & 664 & 548 & 505 & 458 & 451 & 446 \\
& 3 & 648 & 533 & 503 & 466 & 504 & 539 & 662 & 658 & 546 & 501 & 456 & 446 & 445 \\
& 4 & 668 & 666 & 663 & 662 & 661 & 660 & 659 & 667 & 666 & 664 & 663 & 665 & 667 \\
& 5 & 453 & 448 & 449 & 446 & 445 & 441 & 440 & 651 & 539 & 505 & 508 & 543 & 665 \\
\hline $\mathbf{C 3}$ & 1 & 633 & 519 & 490 & 445 & 491 & 517 & 640 & 645 & 526 & 488 & 438 & 433 & 430 \\
& 2 & 625 & 498 & 469 & 424 & 472 & 500 & 630 & 637 & 504 & 468 & 420 & 418 & 412 \\
& 3 & 624 & 486 & 469 & 420 & 469 & 496 & 629 & 631 & 501 & 463 & 418 & 413 & 410 \\
& 4 & 646 & 643 & 640 & 637 & 636 & 634 & 632 & 643 & 640 & 638 & 638 & 640 & 644 \\
& 5 & 430 & 423 & 420 & 413 & 413 & 409 & 408 & 624 & 498 & 468 & 473 & 499 & 631 \\
\hline $\mathbf{D 3}$ & 1 & 642 & 538 & 495 & 458 & 497 & 532 & 654 & 653 & 536 & 493 & 448 & 439 & 436 \\
& 2 & 622 & 509 & 476 & 437 & 478 & 515 & 635 & 634 & 519 & 475 & 428 & 421 & 418 \\
& 3 & 617 & 504 & 469 & 434 & 473 & 510 & 630 & 629 & 511 & 468 & 426 & 416 & 414 \\
& 4 & 654 & 647 & 641 & 634 & 633 & 631 & 629 & 651 & 647 & 640 & 639 & 644 & 649 \\
& 4 & 436 & 427 & 424 & 416 & 416 & 413 & 413 & 621 & 510 & 475 & 478 & 514 & 636 \\
\hline
\end{tabular}

\section{4-ANALYSIS AND DISCUSSION OF TEST RESULTS}

\subsection{Temperature Distribution inside the RC Specimen}

In each specimen, temperature have been measured at (65) points distributed in (5) sections at connection zone. Figures $(9,10)$ illustrate the temperature contours at section (2) inside the specimens (A3and B3) respectively which were exposed to $600{ }^{\circ} \mathrm{C}$ for 2 hour. These specimens casted from normal concrete and reinforced by $\varnothing 12 \mathrm{~mm}$ steel bars. Owing to table (4) and Contours, temperature reading at section 2 (at nodes 1,2,3) inside specimen A3 and B3, it was 644,527 and $497^{\circ} \mathrm{C}$ for specimen A2 while it was 
652,538 and 506 at specimen B2.It can be seen that: temperature increases inside specimens by increasing diameter of reinforcement steel bars.

From table(3) the temperature measured at section (2) inside the specimens (B2 and B3) which exposed to $600{ }^{\circ} \mathrm{C}$ for 1 hour and 2 1hour respectively, temperature reading were 241 and $469^{\circ} \mathrm{C}$ at center of the two sections respectively. It is seen that, temperature increasing by increasing firing time.

The temperature reading at sections (2) inside the specimens (D2) of SCC which were exposed to $600{ }^{\circ} \mathrm{C}$ for 1 hour were $514,277,240$ and 211 at nodes1.2.3.4 respectively while temperature reading were 533, 306, 269 and 241 respectively at the corresponding points on specimen B2 of normal concrete and has same reinforcement like specimen D2.It can said that, temperature propagation less in self-compacted concrete than normal concrete.

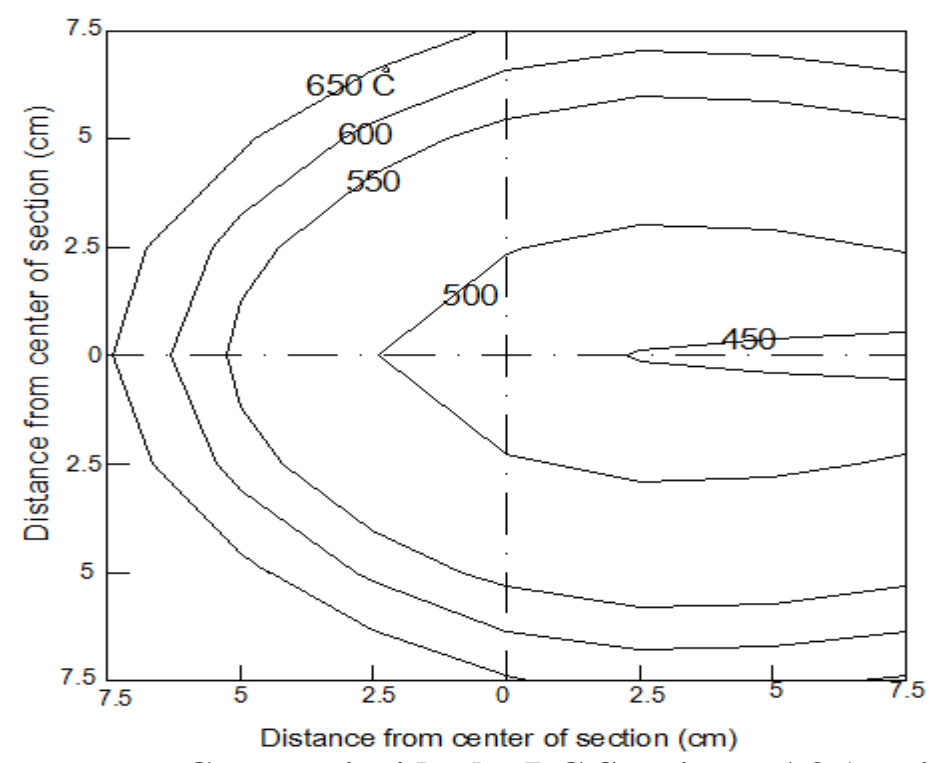

Figure (9)Temperature Contour inside the RC Specimen A3 (section 2) fired for 2 hr at $600{ }^{\circ} \mathrm{C}$ 


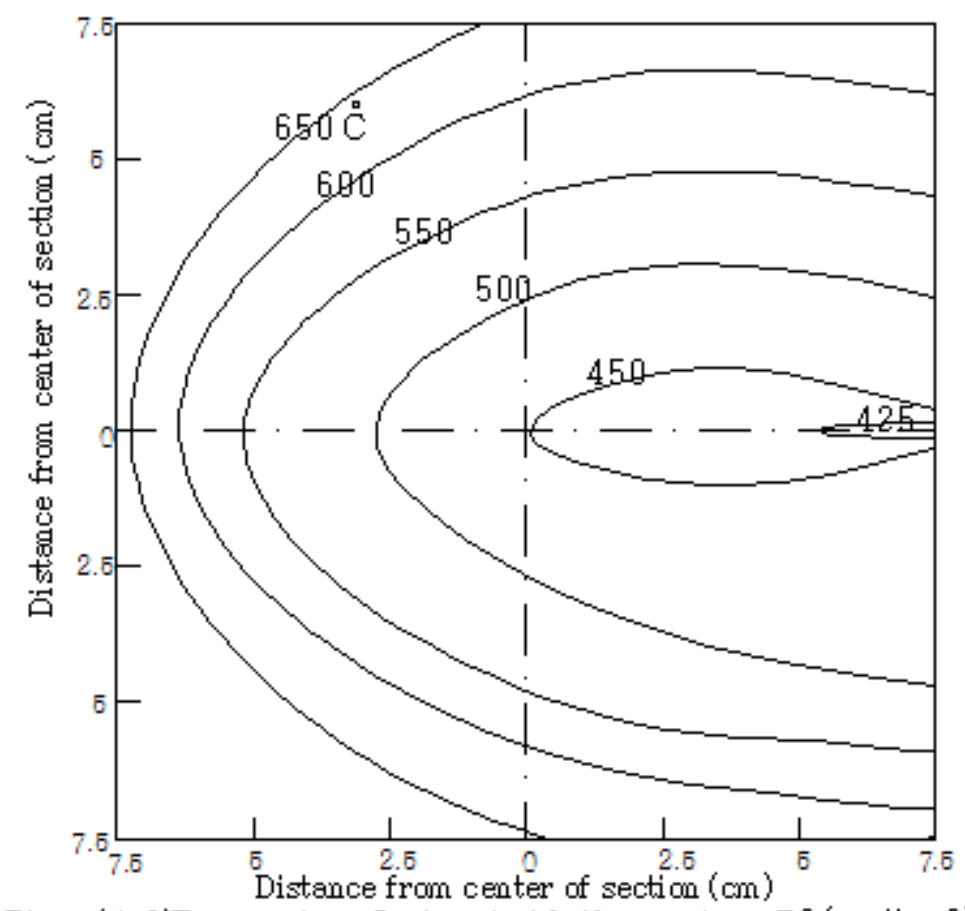

Fisure (4-8)T emperature Contour inside the sp ecimen B3 (section 2)fired for $2 \mathrm{hr}$.

Figure (10) Temperature Contour inside the RC Specimen B3 (section 2) fired for $2 \mathrm{hr}$ at $600{ }^{\circ} \mathrm{C}$

\subsection{Load Deflection Relationship}

The relationship between the applied load and corresponding deflection at different loading points are shown in Figure (11) for specimen (A1) casted from normal concrete. At first cycle of loading which reaching to load 1.5 ton, measured deflection was 11.35, 12.62 and $14.02 \mathrm{~mm}$ for specimen $\mathrm{A} 1, \mathrm{~A} 2$ and $\mathrm{A} 3$ respectively where: $\mathrm{A} 1$ (control) and $\mathrm{A} 2$ and $\mathrm{A} 3$ were fired at $600^{\circ} \mathrm{C}$ for 1 and 2 hour respectively. It is noticed that, deflection increases with increasing fire duration. For group (C) casted from selfcompacted concrete. At first cycle of loading which reaching to load 1.5 ton, measured deflection was $8.53,9.5$ and $10.75 \mathrm{~mm}$ for specimen $\mathrm{C} 1, \mathrm{C} 2$ and $\mathrm{C} 3$ respectively where: $\mathrm{C} 1$ (control), $\mathrm{C} 2$ and $\mathrm{C} 3$ were fired at $600^{\circ} \mathrm{C}$ for 1 and 2hour respectively. It is clear that, deflection increases with increasing fire duration .By making a comparison between deflection of different specimens, it is clear that: deflection decreases with increasing reinforcement ratio for example deflection for specimen A2 was $12.62 \mathrm{~mm}$ where it was $11.61 \mathrm{~mm}$ for specimen $\mathrm{B} 2$ which has more reinforcement ratio and both specimen were fired for $1 \mathrm{hr}$ at $600^{\circ} \mathrm{C}$. Also deflection for specimen $\mathrm{C} 2$ was $9.5 \mathrm{~mm}$ where it was $7.21 \mathrm{~mm}$ for specimen $\mathrm{D} 2$ which has more reinforcement ratio and both specimen were fired for $1 \mathrm{hr}$ at $600^{\circ} \mathrm{C}$. A comparison between deflection of selfcompacted concrete specimens and that of normal concrete, it was found that, deflection decreases for specimen of self-compacted concrete compared with those of normal concrete which have the same reinforcement and fired for the same time and temperature. For example, at load 1.5 ton deflection of specimen B3 of normal concrete was $12.48 \mathrm{~mm}$ where it was $9.34 \mathrm{~mm}$ for specimen D3 of self-compacted concrete. Also, at load 1.5 ton deflection of specimen A3 of normal concrete was $14.02 \mathrm{~mm}$ where it was $10.75 \mathrm{~mm}$ for specimen $\mathrm{C} 3$ of self-compacted concrete. 

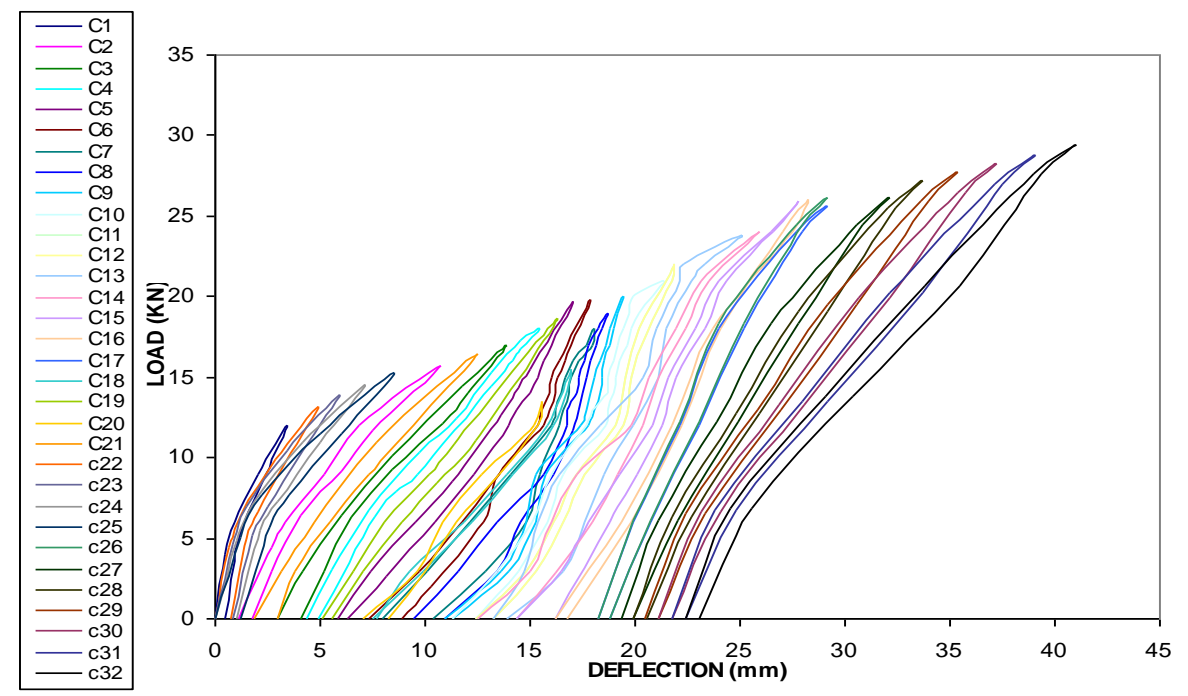

Figure (11) Cyclic Load and Deflection Relationship for RC specimen A1 at $600^{\circ} \mathrm{C}$ for 1 hour

\subsection{Load and Rotation Relationship}

The applied load versus the rotation in all specimens are calculated and It is important to be noticed that, rotation angle was calculated from measured deflection at the beam end directly under applied load. From load- rotation curves, it is clear that for the same load, rotation increases with increasing firing time. For example measured rotation was 0.01,0 .011 and 0.013 radian for specimens B1, B2 (fig.12) and B3 respectively at moment 1.8 m.t. rotation for specimen D1, D2 and D3 at the same load were 0.008, 0.01 and 0.012 radian which means also that rotation decreases in case of self-compacted concrete compared with normal concrete.
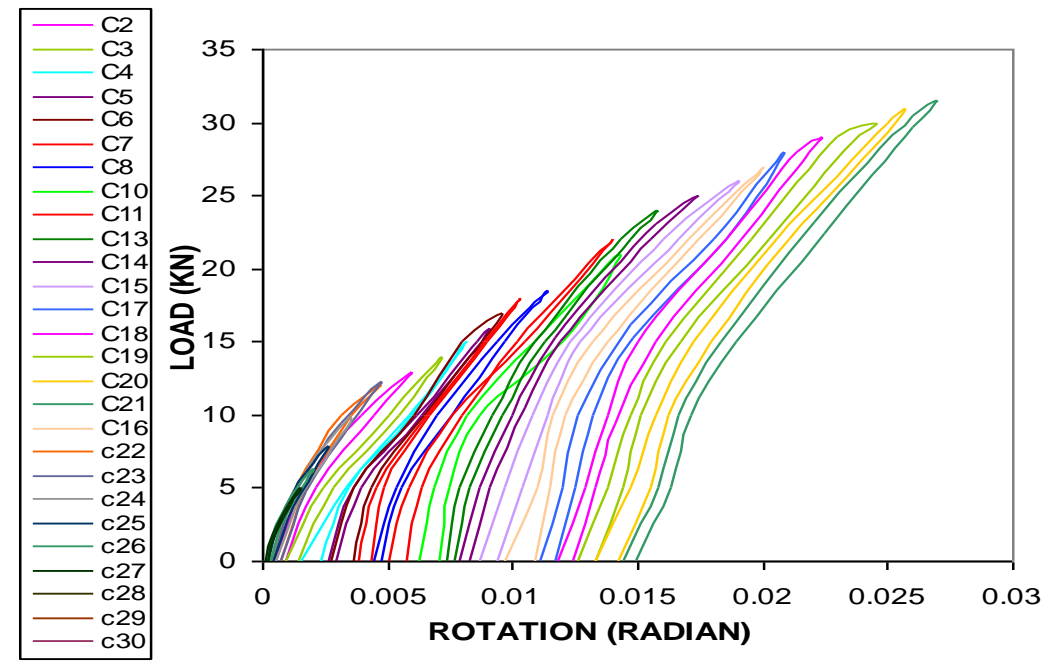

Figure (12) Cyclic Load and Rotation Relationship for RC Specimen B2 at $600^{\circ} \mathrm{C}$ for 1 hour

\subsection{Strain Distribution}

The relation between applied load and strain distribution with the effect of high temperature were studied. The positive values takes place at the upper end of connection where negative values at lower end. From these curves it can be seen that: the strain increases with increasing temperature. For example figure (13) show strain for specimen (A) at load 1.8 ton and strain reaches $1.10 \times 10^{-3} \mathrm{~mm}, 1.16 \times 10^{-3} \mathrm{~mm}$ and $1.36 \times 10^{-3}$ at 
positive sides and reaches $0.60 \times 10^{-3} \mathrm{~mm}, 0.67 \times 10^{-3} \mathrm{~mm}$ and $0.75 \times 10^{-3}$ at negative sides for specimen A1, A2 and A3 respectively. Also from curves it can be conducted that: specimens of self-compacted concrete have less strain values compared with specimens of normal concrete have the same reinforcement and exposure time. For example positive strain for specimen B1, B2 and B3 equal to $0.51 \times 10^{-3} \mathrm{~mm}, 0.65 \times 10_{-3}$ $\mathrm{mm}$ and $0.77 \times 10^{-3}$ at upper side and $0.60 \times 10^{-3} \mathrm{~mm}, 0.83 \times 10^{-3} \mathrm{~mm}$ and $0.99 \times 10^{-3}$ at lower side respectively at load 1.8 ton while for specimen D1, D2 and D3 equal to $0.55 \times 10^{-3} \mathrm{~mm}, 0.59 \times 10^{-3} \mathrm{~mm}$ and $0.63 \times 10^{-3}$ at lower side and equal to $0.41 \times 10^{-3} \mathrm{~mm}$, $0.52 \times 10^{-3} \mathrm{~mm}$ and $0.56 \times 10^{-3}$ at upper side respectively at same load and exposure time.

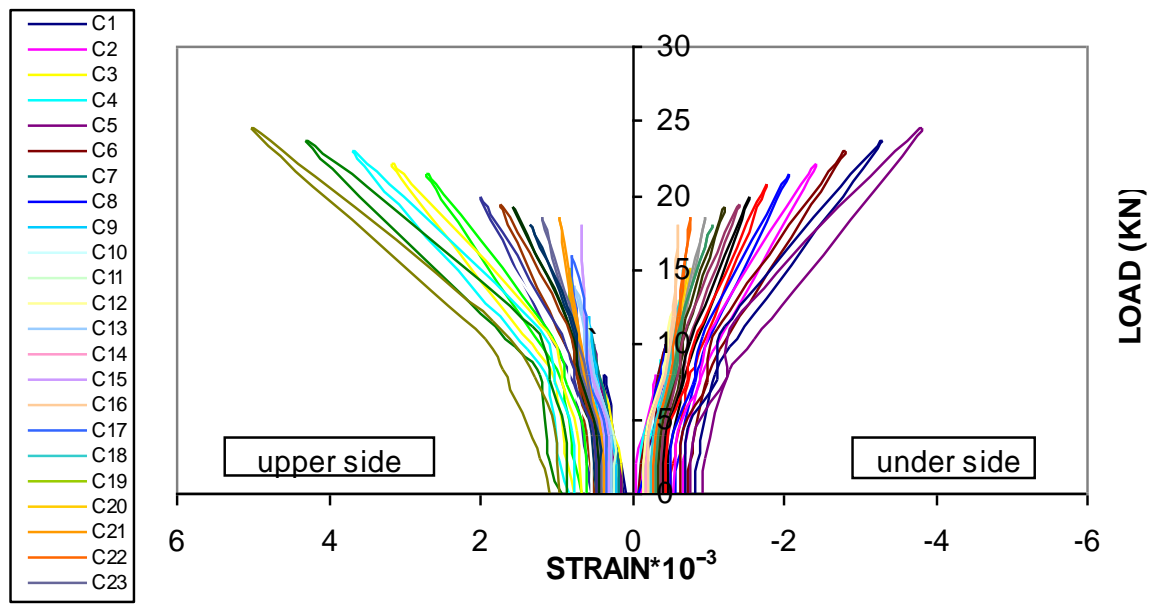

Figure (13) Cyclic loading and Strain Relationship for RC Specimen (A3) at $600^{\circ} \mathrm{C}$ for 2 hour

\subsection{Cracks Propagation, crack pattern and modes of failure}

By studying Cracks for different Specimens at $600^{\circ} \mathrm{C}$ Temperature for 1 hour, it is seen that, number of cracks increases with increasing temperature (fig.14-16). For example: number of cracks for specimens A1, B1, C1 (fig.14) and D1 equal 13,16,10 and 12 respectively while it was found 16, 18,16,12 and 16 for Specimens A2, B2, C2 And D2 respectively. It is also clear that, cracks propagate on self-compacted concrete with higher ratio than that on normal concrete because self Compacted concrete is more dense which leads to more internal pores water pressure which causes more cracks. 
Close up of RC beam column connection details after failure

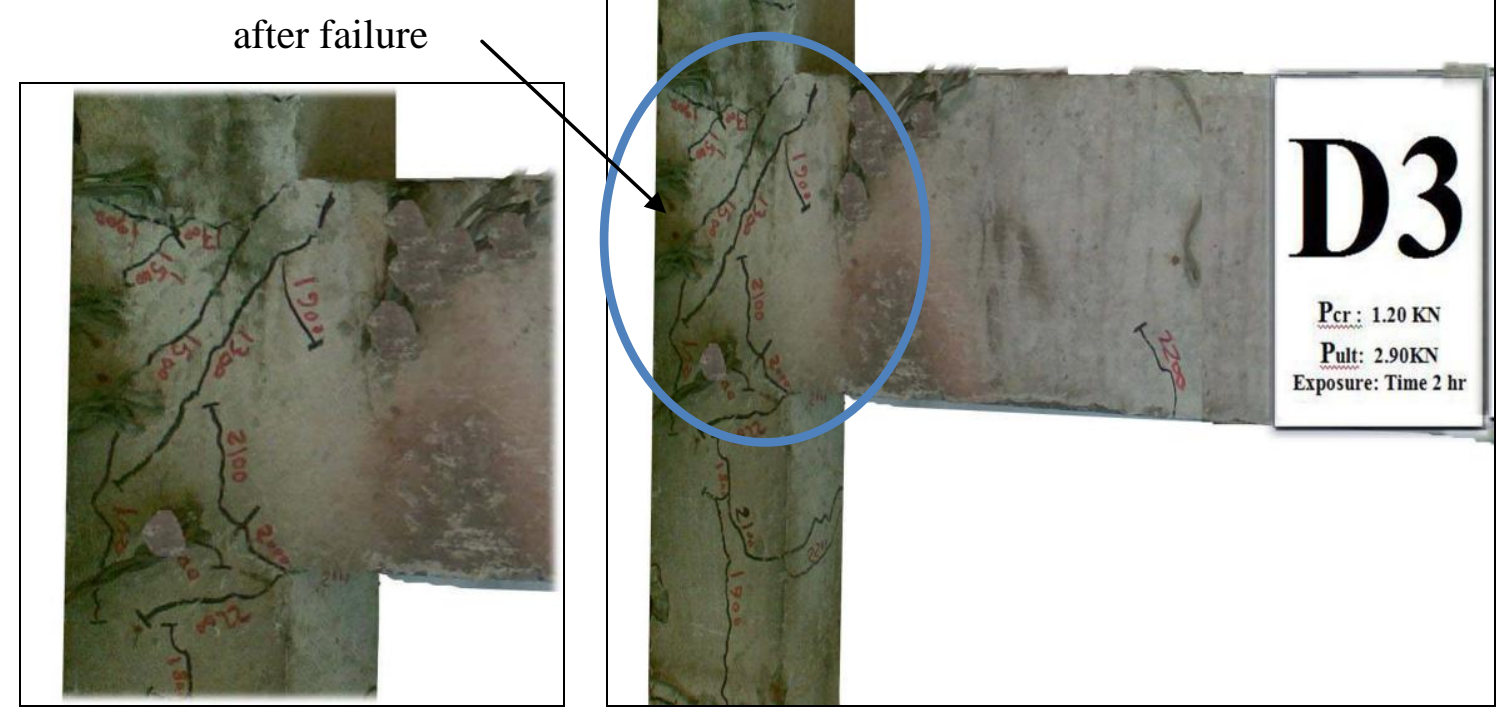

Figure (14) Crack Pattern and modes of failure of $\mathrm{RC}$ Specimen D3 at $600^{\circ} \mathrm{C}$ for 2hr

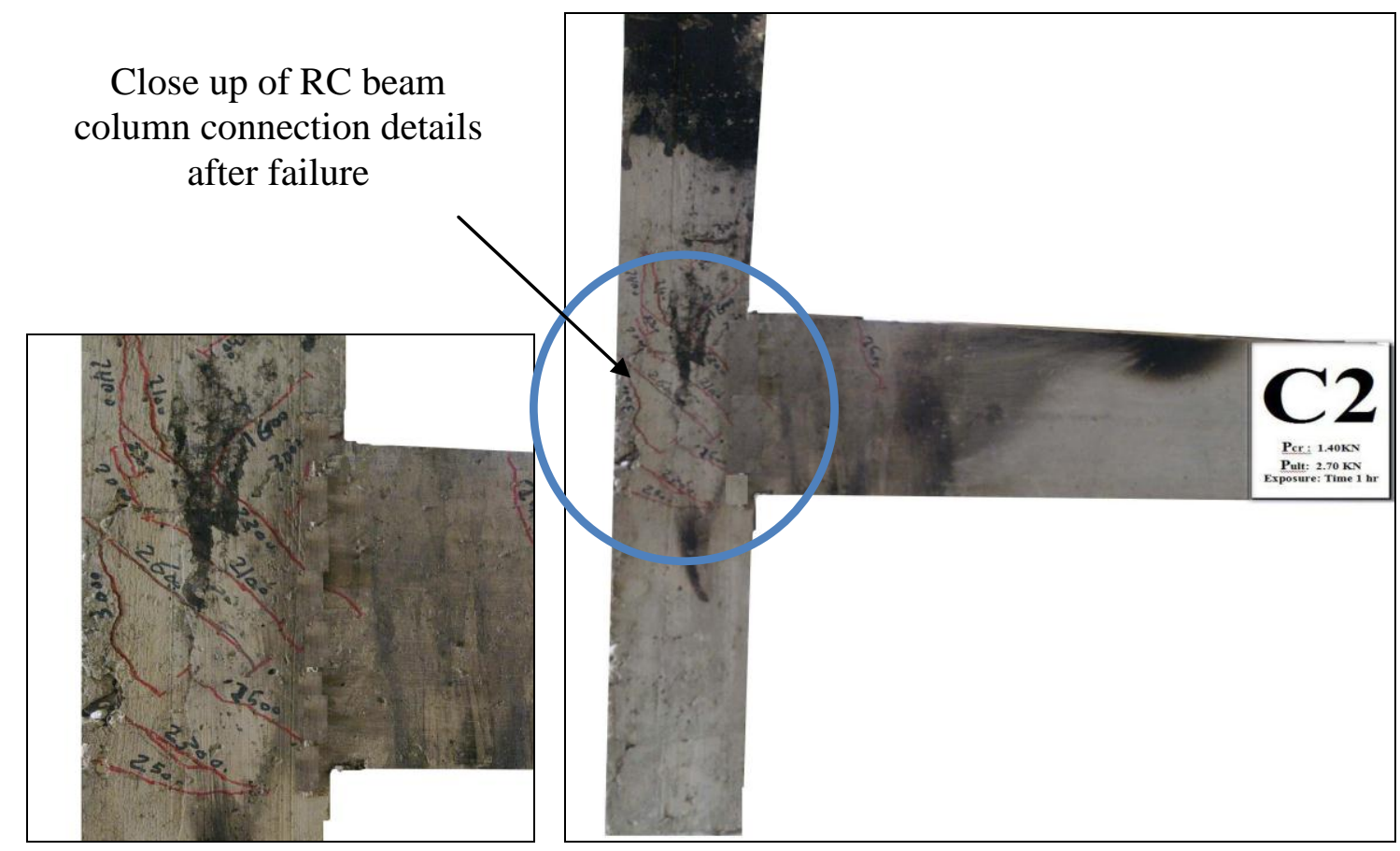

Figure (15) Crack Pattern of Specimen C2 at $600^{\circ} \mathrm{C}$ for $1 \mathrm{hr}$ 


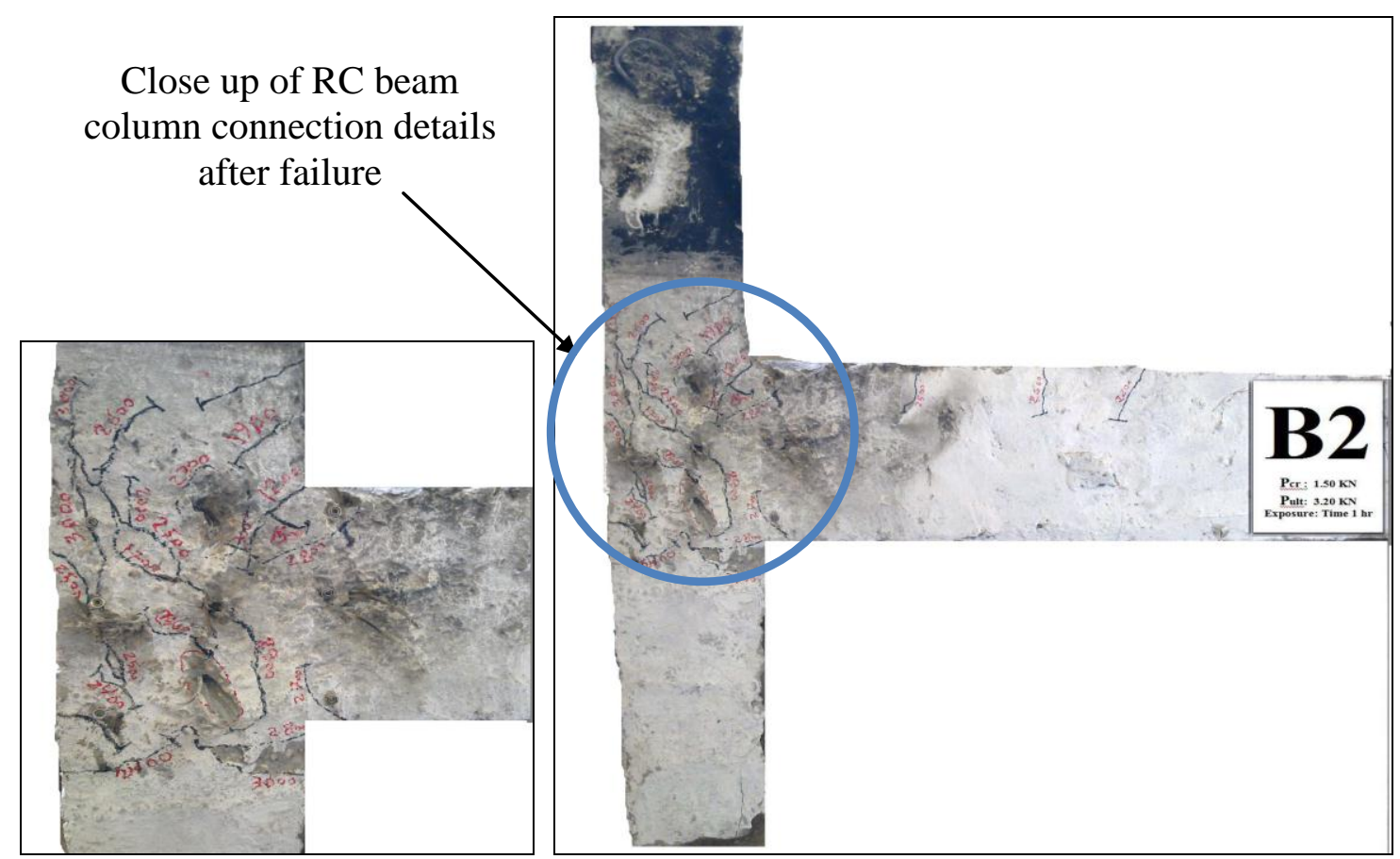

Figure (16) Crack Pattern of Specimen $\mathrm{B2}$ at $600^{\circ} \mathrm{C}$ for $1 \mathrm{hr}$

\subsection{Ductility Index}

In limit and seismic design the ductility of a member is usually expressed as the ratio of the ultimate deformation to the deformation at the first yield. The relative values of moment and curvature when the tension steel first yields and concrete reaches ultimate strain are considered. Member ductility can be expressed in terms of deflection. Definition of ductility index according to ACI is as following;$\mu \mathrm{d}=\Delta \mathrm{u} / \Delta \mathrm{y}$ where:- $\mu \mathrm{d}$ is deflection ductility index.

$\Delta \mathrm{u}$ is the final deflection corresponding to maximum load.

$\Delta y$ is the member deflection at first yielding of the tension reinforcement

Figure (16) to figure (17) show the displacement ductility index for the reinforced beam-column connection specimens. Displacement ductility index for specimens A1, A2 and A3 are 4.41, 3.46 and 3.2 respectively, these results show that, with increasing temperature displacement ductility index decreases.

Displacement ductility index for specimens C1, C2 and C3 are 4.79, 3.94 and 3.72 respectively, by comparing ductility index for group (A) of normal concrete and group (C) of SCC and has the same reinforcement it can be seen that, ductility index decreases in case of SCC. Figure (16) and (17) show with increasing the reinforcement ratio, decreasing displacement ductility index.

Table(6) shows that, Rotation ductility index for specimens A1, A2 and A3 are 4.411, 3.467 and 3.273 respectively, these results show that, with increasing temperature rotation ductility index decreases. Rotation ductility index for specimens C1, C2 and C3 are 4.79, 3.94 and 3.72 respectively Table (6).).By comparing ductility index for group (A) of normal concrete and group (C) of SCC and has the same reinforcement it can be seen that, rotation ductility index decreases in case of SCC. Also with increasing the reinforcement ratio, rotation ductility index. Decreases.

Table(5) Displacement Ductility index for all RC Beam-Column Connections tested Specimens 


\begin{tabular}{|l|c|c|c|c|c|c|}
\hline \multicolumn{2}{|c|}{ Specimen Code } & Failure Load & $\Delta \mathbf{u}$ & Initial Cracking load & $\Delta \mathbf{y}$ & $\boldsymbol{\mu d}$ \\
\hline Group (A) & A1 & 2700 & 28.69 & 1500 & 6.5 & 4.41 \\
& A2 & 2300 & 16.63 & 1100 & 4.8 & 3.46 \\
& A3 & 1800 & 16.66 & 800 & 5.2 & 3.27 \\
\hline Group (B) & B1 & 3500 & 39.69 & 1900 & 8.28 & 4.35 \\
& B2 & 3200 & 22.54 & 1500 & 5.21 & 3.50 \\
& B3 & 2700 & 18.32 & 1100 & 4.49 & 3.20 \\
\hline Group (C) & C1 & 3000 & 30.89 & 1600 & 6.45 & 4.33 \\
& C2 & 2700 & 19.42 & 1400 & 4.93 & 3.37 \\
& C3 & 2100 & 15.65 & 1000 & 4.21 & 3.11 \\
\hline Group (D) & D1 & 3900 & 41.21 & 2300 & 8.39 & 4.08 \\
& D2 & 3500 & 25.81 & 1800 & 5.63 & 4.05 \\
& D3 & 2900 & 23.81 & 1200 & 5.35 & 3.64 \\
\hline
\end{tabular}

Table (6) Rotation Ductility index for all RC Beam-Column Connections tested Specimens

\begin{tabular}{|l|c|c|c|c|c|c|}
\hline \multicolumn{2}{|l|}{ Specimen Code } & $\begin{array}{c}\text { Failure } \\
\text { Load }\end{array}$ & Ou & Initial Cracking load & Oy & $\mu R$ \\
\hline Group (A) & A1 & 2700 & 1.6857 & 1500 & 0.38216 & 4.41109 \\
& A2 & 2300 & 0.9774 & 1100 & 0.28189 & 3.46718 \\
& A3 & 1800 & 0.9905 & 800 & 0.30252 & 3.27433 \\
\hline Group (B) & B1 & 3500 & 1.7086 & 1900 & 0.39247 & 4.35353 \\
& B2 & 3200 & 1.0719 & 1500 & 0.30596 & 3.50338 \\
& B3 & 2700 & 0.9470 & 1100 & 0.29564 & 3.20323 \\
\hline Group (C) & C1 & 3000 & 1.6422 & 1600 & 0.37929 & 4.32969 \\
& C2 & 2700 & 0.9212 & 1400 & 0.27330 & 3.37080 \\
& C3 & 2100 & 0.8960 & 1000 & 0.28762 & 3.11531 \\
\hline Group (D) & D1 & 3900 & 1.6542 & 2300 & 0.40565 & 4.07804 \\
& D2 & 3500 & 1.5798 & 1800 & 0.38961 & 4.05492 \\
& D3 & 2900 & 1.3989 & 1200 & 0.38388 & 3.64411 \\
\hline
\end{tabular}




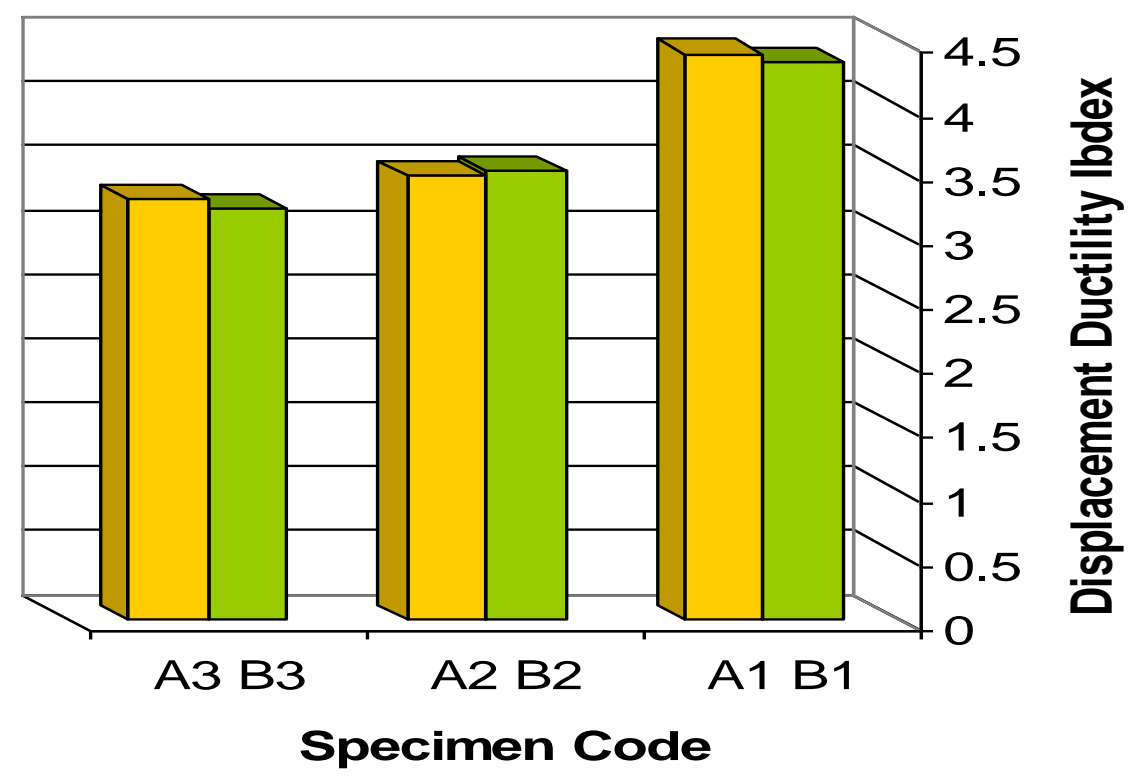

Figure (16) Comparison between Displacement Ductility index for Reinforced Concrete Beam-Column Connections for Group (A) and (B) of normal concrete with different reinforcement ratio and same exposure time

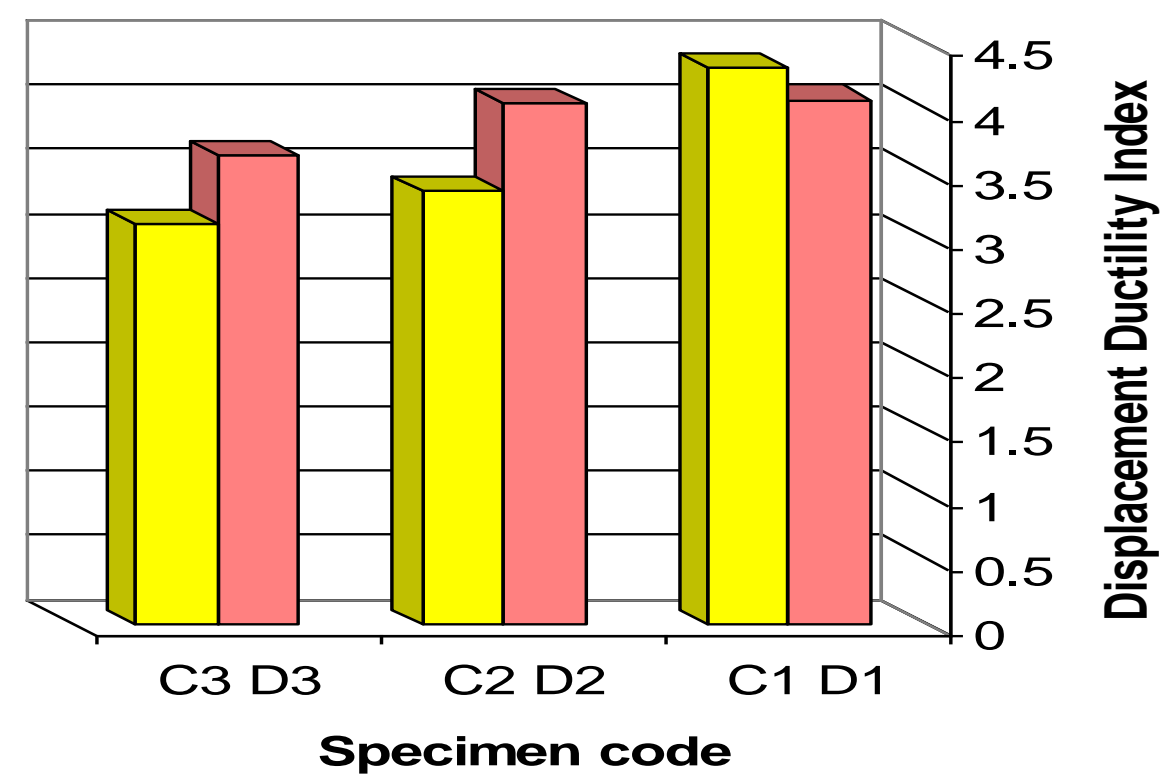

Figure (17) Comparison between Displacement Ductility index for Reinforced Concrete Beam-Column Connection for Group (C) and (D) of SCC concrete with different reinforcement ratio and same exposure time 


\section{5-FINITE ELEMENT ANALYSIS}

Using finite element analysis techniques in the analysis of reinforced concrete structures took very big attention and efforts at last thirty years al least.

In the current analysis, the used program was ANYSIS (version 12.1). ANSYS is a multipurpose finite element package that can be used in the theoretical analysis of structural and electrical problems, water flow and magnetic field. The program is not tailored to solve a given problem with predefined configuration, which means that the program user has to spend some time and effort to select the appropriate element types and build up his own model geometry. Firstly drawing the model then input the material properties, boundary conditions and loads then the solution of structural problem can be obtained. In ANSYS, the models are loaded up to ultimate loads and the efficiency of the model is verified by comparing the ultimate and cracking loads as well as the loaddeflection response with the experimental results. ANSYS offers the feasibility of building three- dimensional models with advanced controls to review the results graphically through output files.. Structural analysis by ANSYS goes through the following main steps:-

1- Defining the element types used in reinforcing the different parts of the model and defining element real constants and material properties.

2- Creating the model geometry and reinforcing the model. fig.(18\}

3- Applying loads.

4- Obtaining the Solution.

5- Reviewing the results. Fig.(19-23)

The sequence of building up the three dimension model and load application procedure can be best described by the commend method to document the current application using ANSYS [26].

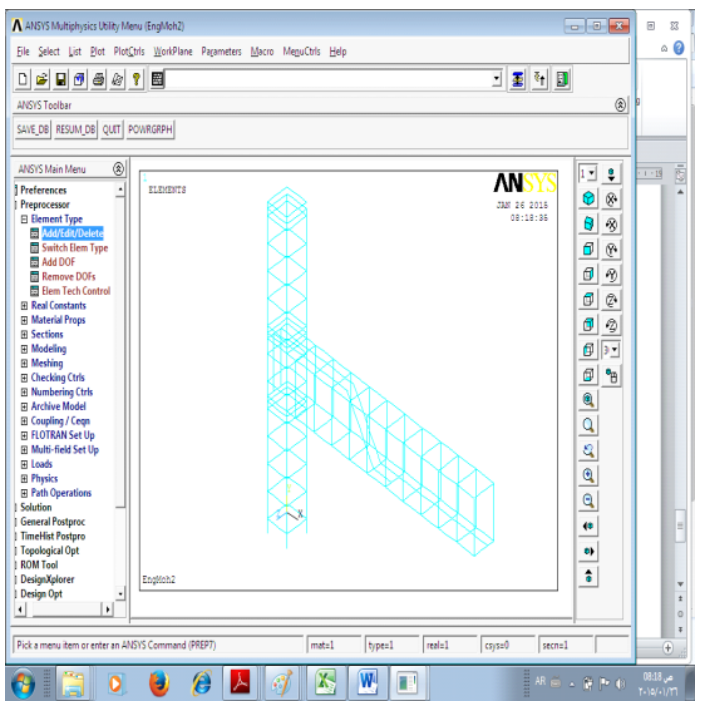

Fig. (18) Specimen with complete reinforcement

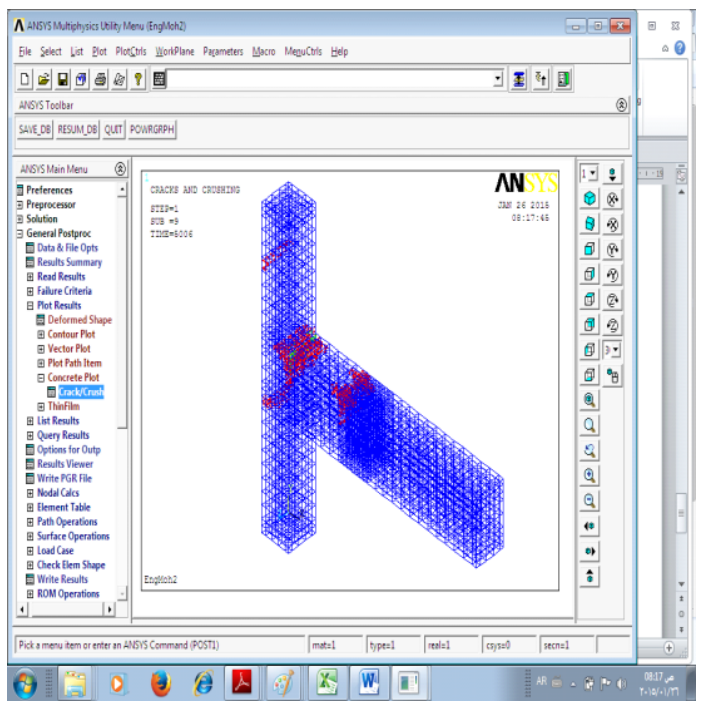

Fig. (19) Cracks at failure loads 


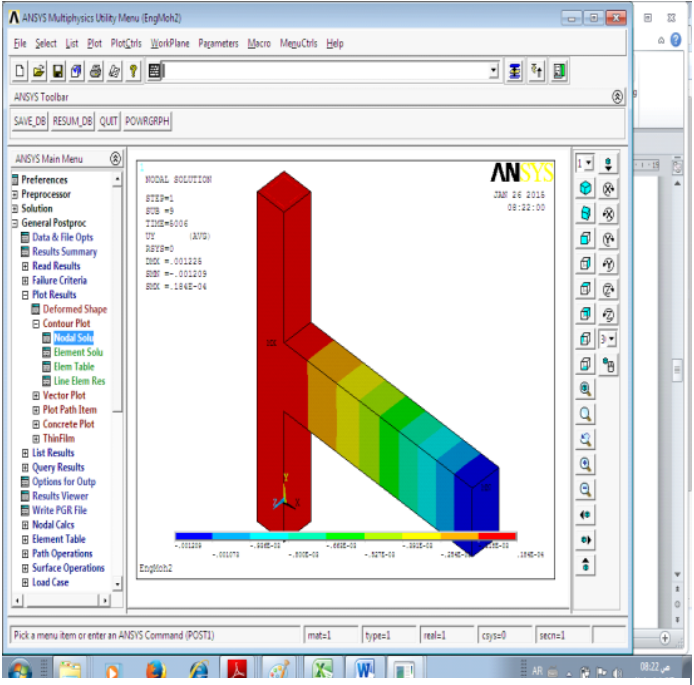

Fig. (20) Deflection at failure loads for specimen (A1)

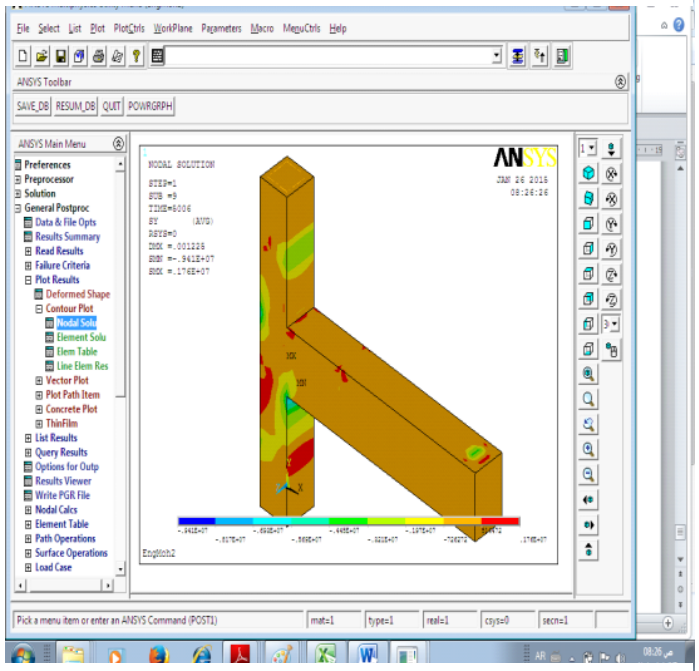

Fig. (22) Normal stresses in y direction for specimen (A1)

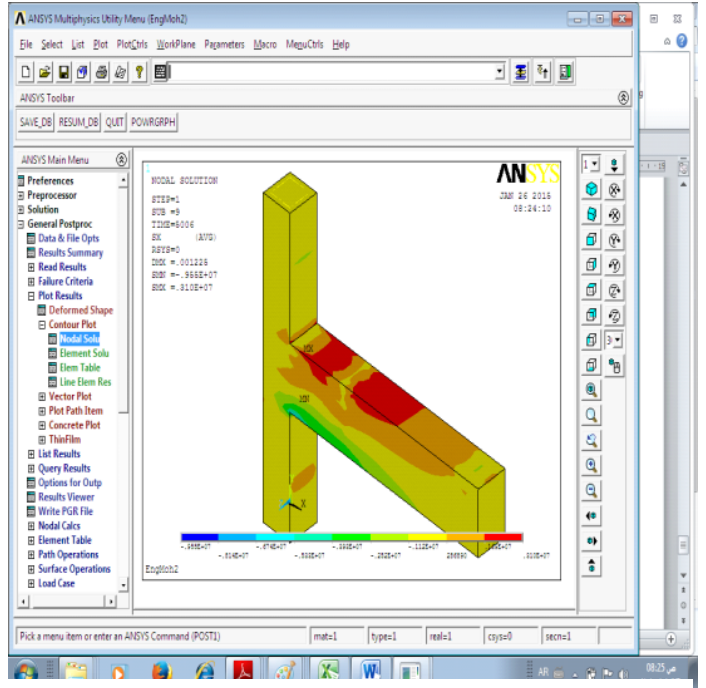

Fig. (21)Normal stresses in X direction for specimen (A1)

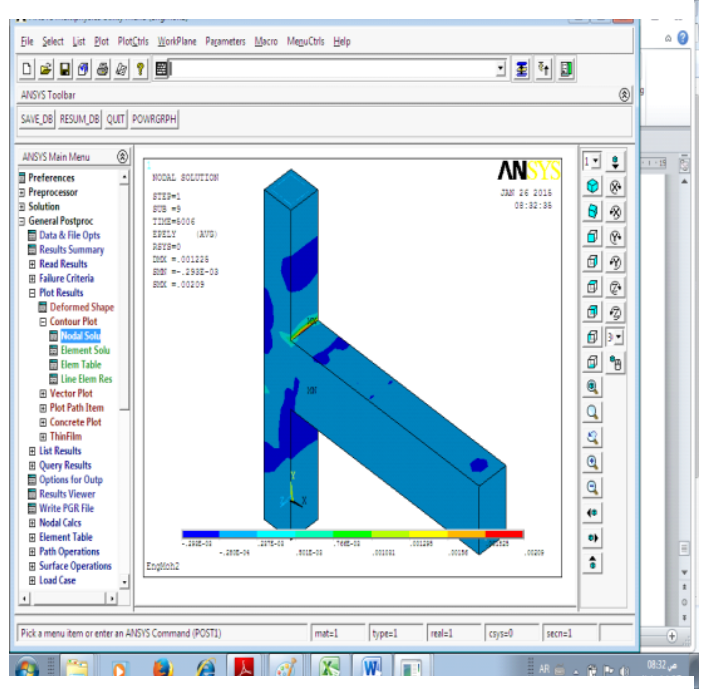

Fig. (23) Strain in y direction for specimen

(A1)

\section{6-COMPARISION BETWEEN EXPERIMENTAL AND ANALYTICAL RESULTS}

\section{s6.1 Characteristics of Load- Deflection Results.}

A comparison between the displacement obtained from experimental work and finite element analysis for different specimens showed good agreement between results obtained from experimental work and finite element analysis as follow:-

1- For specimen A2 (fired at $600^{\circ} \mathrm{C}$ for $1 \mathrm{hr}$ ): the displacement obtained from experimental results is greater than that obtained from analytical analysis by $7 \%$ at load $18 \mathrm{KN}$ where: ultimate load of analytical analysis less than that of experimental work by $18 \%$.

2- For specimen B3 (fired at $600^{\circ} \mathrm{C}$ for $2 \mathrm{hr}$ ): the displacement obtained from experimental results is greater than that obtained from analytical analysis by $4 \%$ at load $16 \mathrm{KN}$ where: ultimate load of analytical analysis is less than that of experimental work by $15 \%$.

3- For specimen D1 at room temperature,: the displacement obtained from experimental 
results is the same that obtained of analytical analysis at load $35 \mathrm{KN}$ where: ultimate load of analytical analysis greater than that of experimental work by $5 \%$.

\subsection{Strain Distribution Characteristics}

1 - For specimen (B1), at load $32 \mathrm{KN}$ the strain reaches $1.58 \times 10^{-3}$ at positive side and reaches $0.72 \times 10^{-3}$ negative side where analytical analysis results showed that. the strain reaches $1.63 \times 10^{-3}$ at positive side and reaches $0.59 \times 10^{-3}$ negative side for specimen (B1) at the same load value

2- For specimen (D3), at load $26 \mathrm{KN}$ the strain reaches $1.72 \times 10^{-3}$ at positive side and reaches $1.92 \times 10^{-3}$ negative side where analytical analysis results showed that. the strain reaches $1.49 \times 10^{-3}$ at positive side and reaches $1.38 \times 10^{-3}$ negative side for specimen (D3) at the same load value.

Important notice came from experimental work and analytical analysis that, compression strain less in SCC than normal concrete for example strain at negative side of specimen B2 (normal concrete) equal $1.51 \times 10^{-3}$ where it equal $0.65 \times 10^{-3}$ for negative side of specimen D2 (self compacted concrete). Also compression strain for specimens $\mathrm{A} 1, \mathrm{C} 1$ equal $0.91 \times 10^{-3}$ and $0.78 \times 10^{-3}$ respectively where $\mathrm{A} 1$ casted from normal concrete and $\mathrm{C} 1$ of self compacted concrete.

\subsection{Cracking Behavior}

Fig. (24-25) show Cracking pattern of all specimen at Ultimate Load. A comparative study for initial crack for specimen of group (A) between the finite element analysis and experimental results. We can concluded that, the initial crack load for specimen A1(control) decreases for experimental results compared with analytical analysis by $9 \%$, but increases for specimens A2 (exposed to $600^{\circ} \mathrm{C}$ for $1 \mathrm{hr}$ ) and A3 (exposed to $600^{\circ} \mathrm{C}$ for $2 \mathrm{hr}$ ) by $4 \%$ and $8 \%$ respectively. Fig. (38) shows a comparative study for initial crack for specimen of group (B) between the finite element analysis and experimental results. We can concluded that, the initial crack load for specimen B1(control) increases for experimental results compared with analytical analysis by $15 \%$, but decreases for specimens B2 (exposed to $600^{\circ} \mathrm{C}$ for $1 \mathrm{hr}$ ) and B3 (exposed to $600^{\circ} \mathrm{C}$ for $2 \mathrm{hr}$ ) by $10 \%$ and $12 \%$ respectively.

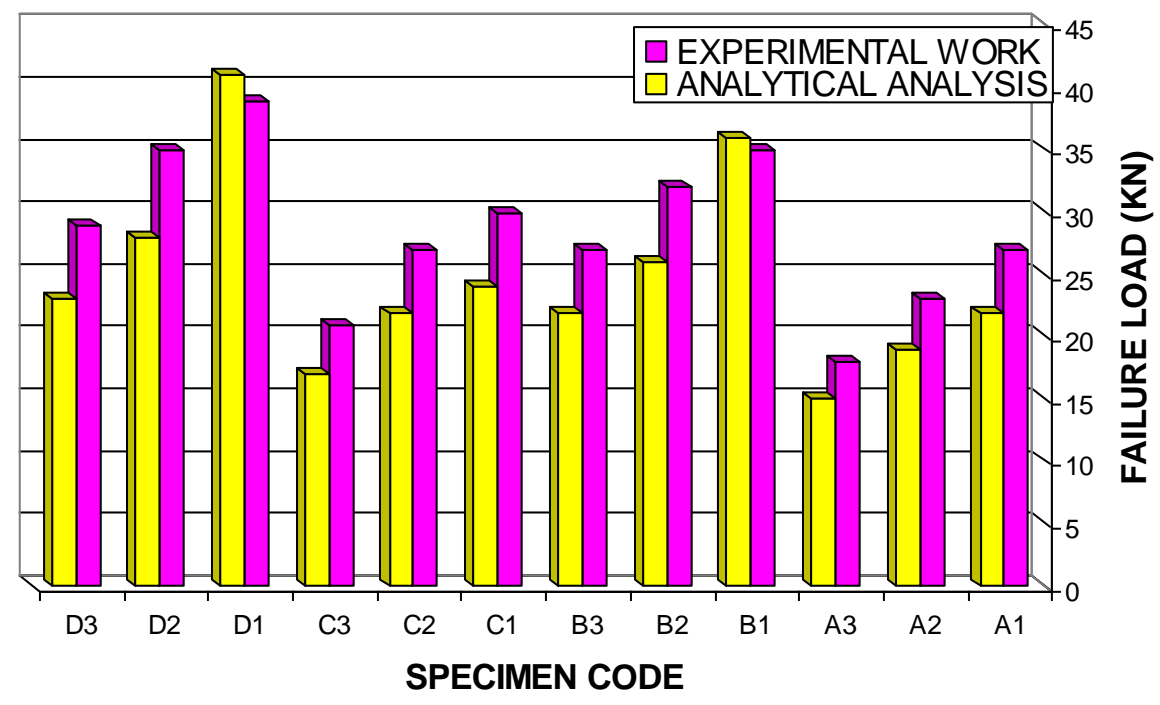

Fig. (24) Comparison of failure Cracking Load for all Specimens (experimentally and analytically) 


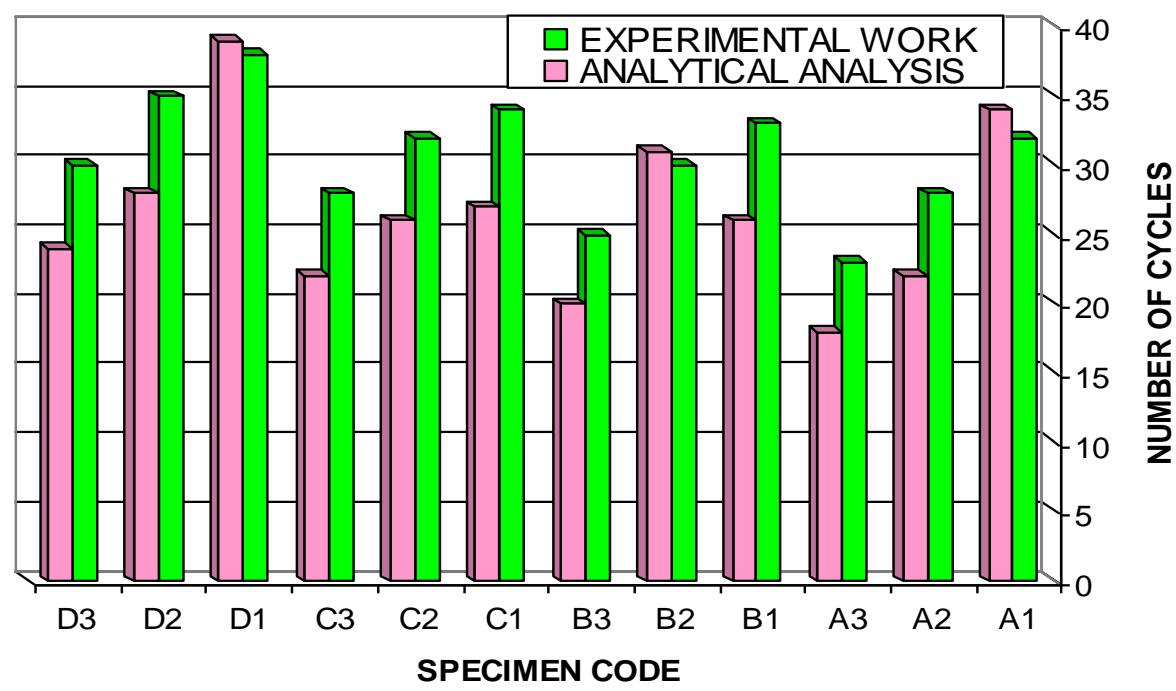

Fig. (25) Comparison of Number of Cyclic Loading for All Specimens (experimentally and analytically)

\section{7. conclusions}

The most important conclusions of this research are summarized as following :-

1- Self- compacted concrete showed higher fire resistance compared with ordinary concrete.

2- Cracking and spilling occurred in self-compacted concrete or ordinary concrete increased with increasing exposure time to fire.

3- The rate of heat propagation inside self-compacted concrete is less than that of ordinary concrete because self-compacted concrete is more dense and contain less bore holes.

4- Increasing reinforcement ratio increases specimen fire resistance under cyclic loading.

5- Increasing exposure time to fire decreases the value of initial crack load, ultimate load and the allowable stress but it increases the strain.

6- Specimen of SCC have number of cyclic loading more than that of corresponding specimens of normal concrete with same reinforcement and exposure time.

7- Number of cycles of loading decreases for all specimens with increasing firing time.

\section{Reference}

[1] V. Belov, V. Morozov, "Fire Resistance of Non-Crack Resistant Flexural Reinforced Concrete Elements", Applied Mechanics and Materials, Vols. 725-726, pp. 15-20, Jan. 2015.

[2] Hachemi, S. Ounis, A. and Cha, S." Evaluating Residual Mechanical and Physical Properties of Concrete at Elevated Temperatures" World Academy of Science, Engineering and TechnologyVol:86 2014-01-04.

[3] ACI / TMS Committee 216" Code Requirements for Determining Fire Resistance of Concrete and Masonry Construction Assemblies ", American Concrete Institute, Detroit, 2014. 
[4] "Structural Design for Fire: A Survey of Building Codes and Standards " National Institute of Standards and Technology Technical Note 1842,120 pages (September2014)

[5] Hai Tan, K. and Thang Nguyen, T." Experimental behavior of restrained reinforced concrete columns subjected to equal biaxial bending at elevated temperatures" Engineering Structures journal,Vol. 56, Nov.2013, PP. 823-836.

[6] Abdel-Hafez, L.M. and Hassan, A.M." Behavior of RC columns retrofitted with CFRP exposed to fire under axial load"Housing and Building National Research Center, February24, 2014.

[7] - Heiza, K. M. " Fire Performance of Both Normal and Self -Compacted Reinforced Concrete Loaded Columns" 5th International Engineering Conference, Mansoura and Sharm El-Shekh, 27-31 March, 2007.

[8] Elkady, H. and Hasan A. " Protection of reinforced concrete beams retrofitted by carbon fibre-reinforced polymer composites against elevated temperatures" Canadian Journal of Civil Engineering, 2010, 37(9): pp.1171-1178, 10.1139/L10059.

[9] Bum,Yean and Hyung- Jum Kim " Experimental Study on Fire Resistance Performance of a Hollow Slab Using a Lightweight Hollow Sphere"10th International Conference of the International Institute for Infrastructure Resilience and Reconstruction (I3R2), 20-22 May 2014, Purdue University, West Lafayette, Indiana -USA.

[10]- Rohit B. Nimse, Digesh D. Joshi, Paresh V. Patel" Behavior of wet precast beam column connections under progressive collapse scenario: an experimental study" International Journal of Advanced Structural Engineering (IJASE), Nov 2014,

[11] Taha, M.Sc." Behavior and Analysis of Reinforced Concrete Beam Column Connections" Msc, Menofia University, Faculty of Engineering, Shebin EL-kom, 2011.

[12] Senthil kumar, E., Murugesan, A. and Thirugnanam, G.S. " Experimental study on behavior of Retrofitted with FRP wrapped RC Beam-Column Exterior Joints Subjected to cyclic loading" INTERNATIONAL JOURNAL OF CIVIL AND STRUCTURAL ENGINEERING Volume 1, No 1, 2010.

[13] Hasan, H. T., Al-Hasan, A. and Naeem, M. A., "Testing of Model of Exterior R.C Beam-Column Connection under Cyclic Loads" Damascus University Journal Vol.25- No. (1) 2009.

[14] Vidjeapriya, R. and Jaya, K. " Experimental Study on Two Simple Mechanical Precast Beam-Column Connections under Reverse Cyclic Loading" Journal of Performance of Constructed Facilities, Volume 27, Issue 4 (August 2013).

[15] Kamal, M. M., Heiza, Kh. M. and Etman, Z. A., " Effect of High Temperature and Fire on The Behavior and Strength of Reinforced Concrete Members cast with Self- Compacting Concrete" Ph.D. thesis, Menofia University, Faculty of Engineering, Shebin EL-kom, 2008

[16] M. A. Helal and Kh. M. Heiza" Effect of Fire and High Temperature on the Properties of Self Compacted Concrete" CICE 2010- The 5th International Conference on FRP Composites in Civil Engineering, September 27-29, 2010, Beijing, China.

[17] Kh. Heiza "State of the art review on assessment of fire-damaged RC structures" , Eighth Conference on Egyptian Rural Development October 2012. Egypt.

[18] Jonaitset, B. and Papinigis V., "Effect OF Long-Term Loading and Fire Temperatures on Mechanical Properties of Concrete" Journal of Civil Engineering and Management ; (2005), Vol. XI, No 4, 283-288. 
[19] Shiedds, T. J., and Silcock, G. W. H., " Building and Fire " http:// ww.biblio.com / 9780582305243. (accessed at Feb. 18, 2010).

[20] Kh. M. Heiza "Design of reinforced concrete structures subjected to fire according to NFPA-5000 - Building construction and safety code" , Second edition 2015.

[21] Egyptian Code of Practice (ECCP203-2007), "Design and Construction for Reinforced Concrete Structures". Research Center for Houses Building and Physical Planning, HBRC, 2007Structures" National Research Center for Housing, Building and Physical Planning .

[22] British Standard Institution, BS 476-10:2009" Fire tests on building materials and structures. Guide to the principles, selection, role and application of fire testing and their outputs " London, England.

[23] "Standard Test Methods for fire tests of building Construction and Materials" ASTM E119-14, American Society for Testing and Materials.

[24] Fire Resistance Tests-Elements of Building Construction, International Standard ISO 834-11, 2014.

[25] "Thermocouple Introduction and theory" http://www. omega.ca/temperature /Z/pdf/z021-032.pdf. ( Accessed at September 6, 2014).

[26]- Nakasone, Y., Yoshimoto, s. and Stolarski, T. A. "Engineering Analysis with ANSYS Software". Elsevier Butterworth- Heinemann, Linacre House, Jordan Hill, Oxford OX28DP, 30Corporate Drive, Burlington, MA01803, First Published 2006. 